OPEN ACCESS

Edited by:

Suzie Chen,

Rutgers University, The State

University of New Jersey,

United States

Reviewed by:

Pietro Formisano,

Università degli Studi di Napoli

Federico II, Italy

Hui Feng,

Boston University, United States

Maria Rosa Ciriolo,

Università degli Studi di Roma Tor

Vergata, Italy

*Correspondence:

Celia R. Berkers

c.r.berkers@uu.n

Specialty section:

This article was submitted to

Cancer Molecular Targets and

Therapeutics,

a section of the journal

Frontiers in Oncology

Received: 10 August 2018

Accepted: 15 October 2018

Published: 02 November 2018

Citation:

Zaal EA and Berkers CR (2018) The

Influence of Metabolism on Drug

Response in Cancer.

Front. Oncol. 8:500.

doi: 10.3389/fonc. 2018.00500

\section{The Influence of Metabolism on Drug Response in Cancer}

\author{
Esther A. Zaal ${ }^{1}$ and Celia R. Berkers ${ }^{1,2 *}$ \\ ${ }^{1}$ Biomolecular Mass Spectrometry and Proteomics, Bijvoet Center for Biomolecular Research, Utrecht University, Utrecht, \\ Netherlands, ${ }^{2}$ Department of Biochemistry and Cell Biology, Faculty of Veterinary Medicine, Utrecht University, Utrecht, \\ Netherlands
}

Resistance to therapeutic agents, either intrinsic or acquired, is currently a major problem in the treatment of cancers and occurs in virtually every type of anti-cancer therapy. Therefore, understanding how resistance can be prevented, targeted and predicted becomes increasingly important to improve cancer therapy. In the last decade, it has become apparent that alterations in cellular metabolism are a hallmark of cancer cells and that a rewired metabolism is essential for rapid tumor growth and proliferation. Recently, metabolic alterations have been shown to play a role in the sensitivity of cancer cells to widely-used first-line chemotherapeutics. This suggests that metabolic pathways are important mediators of resistance toward anticancer agents. In this review, we highlight the metabolic alterations associated with resistance toward different anticancer agents and discuss how metabolism may be exploited to overcome drug resistance to classical chemotherapy.

Keywords: cancer metabolism, drug resistance, bortezomib, cisplatin, BRAF inhibitors, multiple myeloma, melanoma, breast cancer

\section{INTRODUCTION}

Changes in metabolism are one of the emerging hallmarks of cancer cells (1). Although many signaling pathways that are affected by genetic mutations in cancer influence metabolism (2), metabolic alterations are more than just an epiphenomenon (3). Alterations in cellular metabolism sustain rapid production of adenosine triphosphate (ATP) and increased biosynthesis of macromolecules, including nucleotides, lipids and amino acids, and also help maintain cellular redox state $(2,4)$. As such, a rewired metabolism is essential to meet the needs of tumors for rapid cell growth and proliferation.

Both intrinsic and extrinsic mechanisms contribute to the characteristic metabolic alterations in cancer cells. Many different oncogenic as well as tumor suppressor signaling pathways influence metabolism, such as hypoxia-inducible factor 1 (HIF1), p53 and MYC. In addition, cancer metabolism is influenced by the tumor microenvironment, for example the interaction with surrounding cells and the variation in availability of nutrients and oxygen, as extensively reviewed elsewhere (2, 5-12). These mechanisms affect pathways involved in central carbon metabolism, such as glycolysis and the tricarboxylic acid (TCA) cycle, amongst others. As a result, cancer cells have an increased consumption of glucose and glutamine to satisfy their altered metabolic needs. The fact that cancer cells can become addicted to specific metabolic pathways has led to the recent development of novel drugs that target these metabolic vulnerabilities $(13,14)$. 
Resistance to therapeutic agents, either intrinsic or acquired, is currently a major problem in the treatment of cancers and occurs in virtually every type of anti-cancer therapy $(15,16)$. Although increased knowledge about the molecular mechanisms of cancer has led to the development of novel targeted therapeutic compounds that increase progression-free survival, this does not always translate in overall survival benefits due to development of resistance (17). Acquired drug resistance can result from the acquisition of mutations causing decreased drug binding, increased activity of the drug target or the upregulation of multidrug resistance transporters. Acquired resistance can also be the result of various adaptive responses that occur downstream of the drug target and that help cancer cells withstand the effects of the drug [reviewed in (18)]. Examples of such mechanisms are the upregulation of cellular pro-survival pathways, including the activation of DNA repair mechanisms (19), the upregulation of anti-apoptotic proteins $(20,21)$ or autophagy $(22)$. Another mechanism of resistance, that is frequently observed with kinase inhibitor therapy, is the so-called "oncogenic bypass," in which the target pathway is activated through an alternative kinase, even when the primary kinase remains inhibited (2326). Although adaptive resistance can be targeted to improve drug efficacy, heterogeneity and adaptability of cancer cells often leads to new forms of adaptive resistance (27). Therefore, understanding how resistance can be prevented, targeted, and predicted becomes increasingly important to improve cancer therapy.

Recent studies show that the response to widely-used first-line chemotherapy is substantially influenced by the metabolic state of the cells and that cancer cells rewire their metabolism in response to chemotherapeutic drugs. We postulate that metabolic rewiring is a novel and important mechanism of adaptive resistance. Here, we will introduce the main features of cancer metabolism in relation to drug resistance and review specific metabolic programs and adaptations that exist in drug-resistant tumors. We will discuss how these adaptations depend both on the drug and the origin of the tumor and how they contribute to drug resistance, focussing on widely-used chemotherapeutics, including proteasome inhibitors (multiple myeloma), EGFR inhibitors (breast cancer), cisplatin (lung cancer/ovarian cancer) and BRAF inhibitors (melanoma). Finally, we will illustrate how targeting metabolism could overcome drug resistance to standard chemotherapy.

\footnotetext{
Abbreviations: 2-DG, 2-deoxyglucose; 6-AN, 6-aminonicotinamide; ATP, adenosine triphosphate; $\mathrm{BSO}$, buthionine sulfoximine; $\mathrm{CPT1}$, carnitine palmitoyl transferase 1; DCA, dichloroacetate; ETC, electron transport chain; FASN, fatty acid synthase; FH, fumarate hydratase; G6PD, glucose-6-phosphate dehydrogenase; GCLC, glutathione cysteine ligase; GLS, glutaminase; GLUT, glucose transporter; GSH, glutathione; HIF1, hypoxia inducible factor 1; HK2, hexokinase 2; IDH1, isocitrate dehydrogenase 1; IDH2, isocitrate dehydrogenase 2; LDHA, lactate dehydrogenase A; MCT4, monocarboxylate transorter 4; ME, malic enzyme; NQO1, NADPH dehydrogenase; OAA, oxaloacetate; OXPHOS, oxidative phosphorylation; PDK1, pyruvate dehydrogenase kinase 1; PFK2, phosphofructokinase 2; PGAM1, phosphoglycerate mutase 1; PHGDH, 3phosphoglycerate dehydrogenase; PKM2, pyruvate kinase isoform M2; PPP, pentose phosphate pathway; ROS, reactive oxygen species; SDH, succinate dehydrogenase; SOD2, superoxide dismutase 2; SSP, serine synthesis pathway; TCA, tricarboxylic acid.
}

\section{CANCER METABOLISM}

\section{Changes in Metabolism Are Essential to Sustain Cancer Cell Growth and Proliferation}

Glycolysis is the main pathway that is responsible for the breakdown of glucose, and converts glucose to pyruvate in several steps (Figure 1). Glycolysis results in the production of a limited amount of energy in the form of ATP and reducing equivalents in the form of NADH. Pyruvate can subsequently be fed into the mitochondrial TCA cycle, where it is condensed with oxaloacetate to produce citrate. A series of subsequent reactions yields reducing equivalents in the form of $\mathrm{NADH}$ and $\mathrm{FADH}_{2}$, which can be oxidized in the electron transport chain (ETC) complexes to ultimately produce ATP in a process called oxidative phosphorylation (OXPHOS) (28, 29) (Figure 1). Although ATP production via OXPHOS is more efficient, the majority of cancer cells generate most of their ATP through glycolysis, even in the presence of oxygen (30). This phenomenon is known as aerobic glycolysis or "the Warburg effect" and is characterized by an increased glycolytic rate, whereby pyruvate is converted to lactate and secreted by the cell instead of being funneled into the TCA cycle.

Cancer cells sustain their high glycolytic rates in several ways. For example, glycolytic cancers often meet the high demand for extracellular glucose by overexpression of glucose transporters (GLUTs) $(31,32)$. They also show higher levels of monocarboxylate transporter 4 (MCT4), which is responsible for lactate export and thereby helps both in maintaining intracellular $\mathrm{pH}$ and in continuing glycolysis $(33,34)$. In addition, the secretion of lactate could aid in creating an acidic extracellular tumor environment that favors tumor growth by promoting migration and invasion $(35,36)$. Interestingly, cancer cells seem to rely more on specific isoforms of glycolytic enzymes, making these promising targets to specifically inhibit glycolysis in cancer cells (Figure 1) (14). For example, the M2 isoform of pyruvate kinase (PKM2) is preferentially expressed over other isoforms in most cancer cells (37). PKM2 catalyzes the final step in glycolysis, and cancer cells are thought to regulate its activity to either increase glycolytic rates or divert glycolytic intermediates to biosynthetic pathways (38), as detailed below. Cancers can also be more dependent on isoforms of hexokinase (HK2) $(39,40)$ and lactate dehydrogenase (LDHA) (41), or overexpress an isoform of phosphoglycerate mutase (PGAM1) $(42,43)$ (Figure 1). Finally, several metabolic enzymes that regulate glycolysis are highly expressed in cancer, including pyruvate dehydrogenase kinase 1 (PDK1) (44) and phosphofructokinase 2 (PFK2) (45, 46), allowing cancer cells to easily adapt glycolytic flux to meet their needs.

\section{Diverting Glycolytic Resources Toward the Production of Building Blocks}

Why cancer cells prefer the less efficient glycolysis over OXPHOS for ATP production is not fully understood. Initially, Warburg hypothesized that cancer cells increase glycolytic activity because 


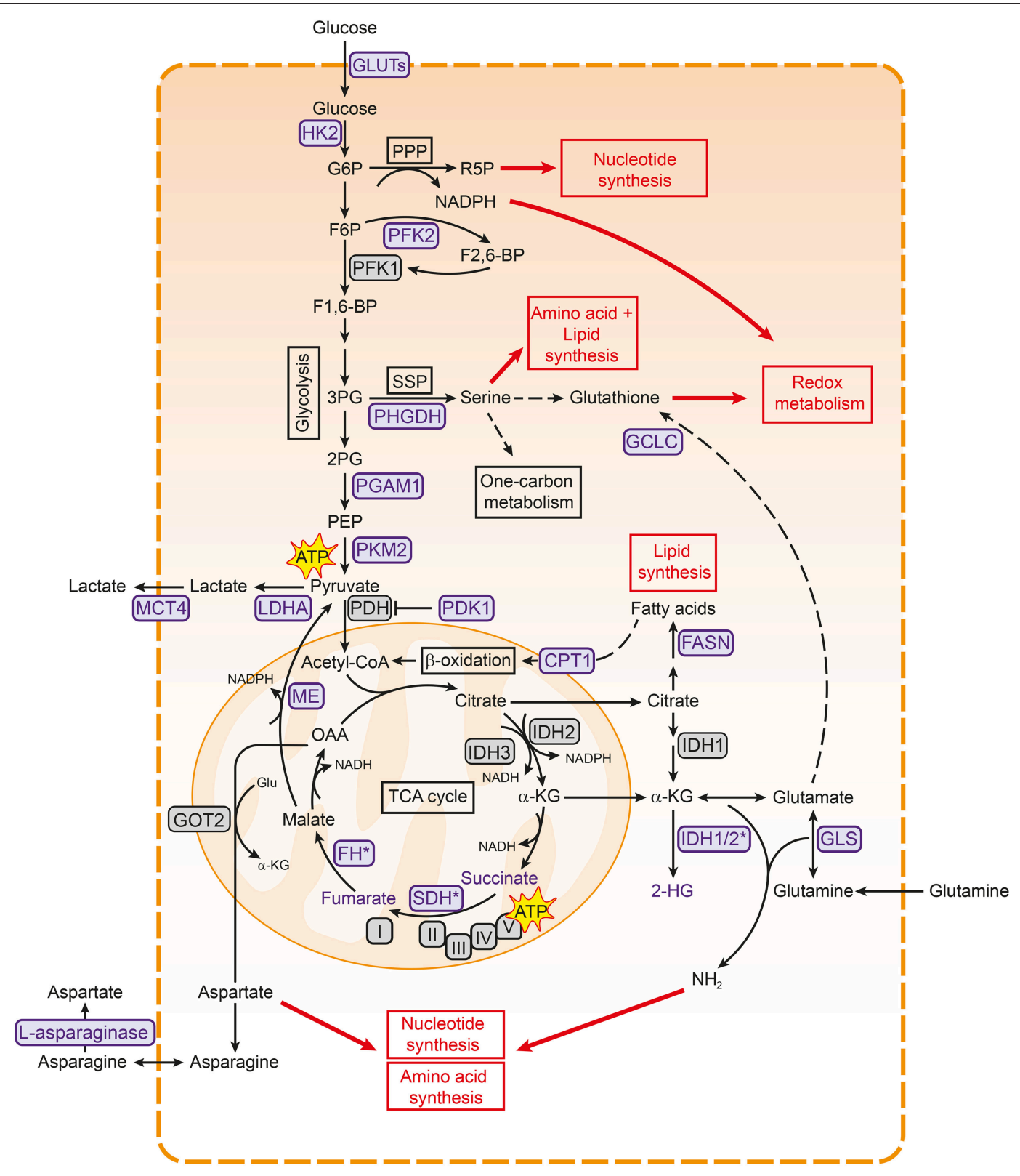

FIGURE 1 | Metabolic pathways associated with cancer. Pathways involved in central carbon metabolism are presented. Metabolic enzymes that are often upregulated in cancer and serve as potential therapeutic targets are shown in purple. These metabolic pathways are involved in the synthesis of building blocks for macromolecules and redox homeostasis, needed for cell proliferation (shown in red boxes). 2PG, 2-phosphoglycerate; 3PG, 3-phoshoglycerate; ATP, adenosine triphosphate; CPT1, carnitine palmitoyltransferase I; F1,6-BP, fructose-1,6-bisphosphate; F2,6-BP, fructose-2,6-bisphosphate; F6P, fructose- 6-phosphate; FASN, fatty acid synthase; FH, fumarase; G6P, glucose-6-phosphate; GCLC, glutamate-cysteine ligase; GLS, glutaminase; Glu, glutamate; GLUT, glucose transporter type; HK2, hexokinase 2; I, complex I; IDH, isocitrate dehydrogenase; II, complex II; III, complex III; IV, complex IV; LDHA, lactate dehydrogenase A; MCT4, monocarboxylate transporter 4; ME, malic enzyme; OAA, , oxaloacetate; PDH, pyruvate dehydrogenase complex; PDK1, pyruvate dehydrogenase kinase 1; PEP, phosphoenol pyruvate; PFK1, phosphofructokinase 1; PFK2, phosphofructokinase 2; PGAM1, phosphoglycerate mutase 1; PHGDH, 3-phosphoglycerate dehydrogenase; PKM2, pyruvate kinase M2; PPP, pentose phosphate pathway; R5P, ribose 5-phosphate; SDH, succinate dehydrogenase; SSP, serine synthesis pathway; TCA, tricarboxylic acid cycle; V, complex V.

of impaired mitochondrial function (30). Indeed, several cancers are associated with mutations in TCA cycle enzymes, supporting this hypothesis $(47,48)$ (Figure 1). However, cancer cells also prefer glycolysis when mitochondrial function is intact $(49,50)$, suggesting that glycolysis confers other advantages to cancer cells. As several glycolytic intermediates can branch off into key biosynthetic pathways to generate nucleotides, amino acids and fatty acids, one of the main functions of the increased glycolytic 
rates is likely to meet the increased biosynthetic needs of cancer cells (4).

One of the pathways that branches of glycolysis is the pentose phosphate pathway (PPP), which both sustains the biosynthesis of macromolecules and maintains redox homeostasis (Figure 1) (51-53). The PPP produces ribose-5-phosphate for nucleotide synthesis, and regenerates NADPH to provide reducing power for glutathione and thioredoxin, both of which can capture the reactive oxygen species (ROS) that are produced during rapid cell proliferation. Glucose-6-phosphate dehydrogenase (G6PD), which catalyzes the first step of the PPP, is upregulated in numerous cancer cells, underlining the importance of the PPP in cancer metabolism $(53,54)$. In addition, the glycolytic intermediate 3-phosphoglycerate is used for the synthesis of the non-essential amino acid serine and downstream metabolites through the serine synthesis pathway (SSP; Figure 1). The SSP has emerged as a key pathway in cancer metabolism. Serine is needed to synthesize reduced glutathione and phospholipids and also plays a major role in the one-carbon cycle, which sustains both the biosynthesis of nucleotides and NADPH regeneration $(55,56)$. In line with this role, the SSP is often highly active in cancer cells and 3-phoshoglycerate dehydrogenase (PHGDH), the first and rate-limiting enzyme in this pathway, is frequently upregulated in different cancers $(57,58)$. The influx of glycolytic intermediates into the SSP and PPP can also be regulated by the glycolytic enzymes PKM2 (59-62) and PGAM1 (63). Lower activity of these enzymes results in accumulation of upstream metabolites, which then enter the SSP and PPP. Cancer cells thus employ various strategies to tune the diversion of glycolytic metabolites into biosynthetic pathways, underscoring the importance of glycolytic regulators in cancer metabolism (4).

\section{Rewiring of Glutamine Metabolism in the Mitochondria}

As intermediates of the TCA cycle are also building blocks for the biosynthesis of lipids and nucleotides (Figure 1), the TCA cycle is as important as glycolysis for cancer cell anabolism. Citrate can be used for fatty acid synthesis via fatty acid synthase (FASN), which has shown to be important in cancer cells [reviewed in (64)]. Aspartate, which is synthesized from oxaloacetate and glutamate, is important for nucleotide synthesis, making the TCA cycle important for DNA synthesis (65). In addition, malate can exit the TCA cycle via malic enzyme (ME), resulting in the production of NADPH (Figure 1) (66).

Because many TCA intermediates are shuttled into biosynthetic pathways, a new supply of carbons is needed to maintain TCA cycle activity, a process called anaplerosis. One of the most important anaplerotic pathways in cancer is glutaminolysis, in which glutamine is used to replenish the TCA cycle. Indeed, glutamine is the second most consumed metabolite in proliferating cells in cell culture $(67,68)$. It has been shown that glutamine is needed for protein-, fatty acid-, and nucleotide synthesis, but is also important for redox homeostasis and protein $O$-GlcNAcylation $(66,69,70)$. As a result, many tumor cells are more dependent on glutamine as compared to healthy cells $(71,72)$.
After glutamine enters the cell, it is converted to glutamate by glutaminase (GLS). Glutamate in turn can be further converted to $\alpha$-ketoglutarate that can subsequently enter the TCA cycle (Figure 1). Via glutamate, glutamine is used for the production of the amino acids aspartate and proline. Both these amino acids can be limiting for proliferation in cancer cells $(65,73,74)$. In addition, glutathione cysteine ligase (GCLC), which converts glutamate to GSH, is highly expressed in several cancers $(75,76)$. These examples underscore the importance of glutamine and downstream pathways in cancer growth.

However, a range of other metabolites has also been described to fuel the TCA cycle in cancer. Fatty acids are not only important components of membranes, but are also energy-rich compounds that can be degraded to provide ATP via $\beta$-oxidation (77). Carnitine palmitoyl transferase 1 (CPT1) conjugates fatty acids with carnitine to translocate them to mitochondria, where $\beta$ oxidation takes place (Figure 1). CPT1C, an atypical isoform of CPT1, is highly expressed in cancers and promotes $\beta$-oxidation and ATP production (78). In addition, lactate (79), acetate (80), and branched chain amino acids (BCAA) (81) can provide the TCA cycle with carbons, illustrating the complexity of cancer metabolism.

Interestingly, TCA cycle enzymes are emerging as mediators of malignant transformation in cancer. Fumarate hydratase (FH) and succinate dehydrogenase (SDH) are tumor suppressors (Figure 1). Loss-of-function mutations in these genes are associated with tumorigenesis [reviewed in (82)] and result in the accumulation of succinate and fumarate, respectively, both of which function as oncometabolites $(83,84)$. Mutations in isocitrate dehydrogenase 1 (IDH1) and IDH2 are present in many cancers $(85,86)$ and result in the production of the oncometabolite 2-hydroxyglutarate (87). The accumulation of these oncometabolites promote cancer in various ways, including stabilization of HIF1 and DNA hypermethylation via inhibition of $\alpha$-ketoglutarate-dependent dioxygenases [as reviewed in (48, 84)].

\section{METABOLISM AND DRUG RESISTANCE}

It is becoming increasingly clear that changes in metabolism influence drug response to established first-line chemotherapy in several cancers, identifying metabolic rewiring as a novel, and important mechanism of adaptive resistance. Table 1 gives a comprehensive overview of studies linking metabolism to drug resistance in cancer.

In this section, we provide a more in-depth analysis of the four cancer-drug combinations on which most research has been done: Proteasome inhibitors for multiple myeloma, EGFR inhibitors for breast cancer, cisplatin for lung and ovarian cancer, and BRAF inhibitors for melanoma.

\section{Metabolism Is Linked to Anticancer Drug Resistance to Proteasome Inhibitors}

Proteasome inhibitors are a cornerstone in the treatment of multiple myeloma $(143,144)$, with bortezomib being the first clinically available proteasome inhibitor. Proteasome inhibition 
TABLE 1 | Overview of metabolic alterations associated with drug resistance in cancer.

\begin{tabular}{|c|c|c|c|c|}
\hline $\begin{array}{l}\text { Cancer } \\
\text { type }\end{array}$ & $\begin{array}{l}\text { Pathways } \\
\text { associated } \\
\text { with } \\
\text { resistance }\end{array}$ & Therapy & $\begin{array}{l}\text { Target in } \\
\text { resistance } \\
\text { (proposed } \\
\text { therapy) }\end{array}$ & References \\
\hline \multicolumn{5}{|c|}{ MULTIPLE MYELOMA } \\
\hline & Glycolysis & Bortezomib & LDHA, PDK1 & $(88-91)$ \\
\hline & $\begin{array}{l}\text { Mitochondrial } \\
\text { energy } \\
\text { metabolism }\end{array}$ & $\begin{array}{l}\text { Bortezomib, } \\
\text { Carfilzomib }\end{array}$ & SOD2 (2ME), & $(92-95)$ \\
\hline & $\begin{array}{l}\text { Redox } \\
\text { metabolism }\end{array}$ & Bortezomib & - & $(91,93,96)$ \\
\hline & Glutaminolysis & $\begin{array}{l}\text { Bortezomib, } \\
\text { Carfilzomib }\end{array}$ & GLS (CB-839) & $(92)$ \\
\hline & $\begin{array}{l}\text { Mevalonate } \\
\text { pathway }\end{array}$ & Bortezomib & $\begin{array}{l}\text { HMG-CoA } \\
\text { (simvastatin) }\end{array}$ & $(97)$ \\
\hline & $\begin{array}{l}\text { Serine } \\
\text { synthesis }\end{array}$ & Bortezomib & PHGDH & $(91)$ \\
\hline & $\begin{array}{l}\text { Pentose } \\
\text { phosphate } \\
\text { pathway }\end{array}$ & Bortezomib & - & $(91)$ \\
\hline \multicolumn{5}{|c|}{ LUNG CANCER } \\
\hline & $\begin{array}{l}\text { Mitochondrial } \\
\text { energy } \\
\text { metabolism }\end{array}$ & Cisplatin & - & (98) \\
\hline & Glutaminolysis & Cisplatin & $\begin{array}{l}\text { xCT antiporter } \\
\text { (riluzole) }\end{array}$ & $(98,99)$ \\
\hline & $\begin{array}{l}\text { Redox } \\
\text { metabolism }\end{array}$ & Cisplatin & $\begin{array}{l}\text { ASS, TRX1 } \\
\text { (Elesclomol), } \\
\text { GCLC }\end{array}$ & $(100-103)$ \\
\hline & Glycolysis & $\begin{array}{l}\text { Cisplatin, } \\
\text { Paclitaxel, } \\
\text { Carboplatin }\end{array}$ & $\begin{array}{l}\text { HK2 (2-DG), } \\
\text { mTOR, PDK2 } \\
\text { (DCA), PKM2 } \\
\text { (metformin) }\end{array}$ & $\begin{array}{l}(99,104- \\
106)\end{array}$ \\
\hline \multicolumn{5}{|c|}{ OVARIAN CANCER } \\
\hline & Glycolysis & Cisplatin & 2-DG & $(107,108)$ \\
\hline & $\begin{array}{l}\text { Pentose } \\
\text { phosphate } \\
\text { pathway }\end{array}$ & Cisplatin & G6PD (6-AN) & $(107,109)$ \\
\hline & $\begin{array}{l}\text { Redox } \\
\text { metabolism }\end{array}$ & Cisplatin & $\begin{array}{l}\text { GCLC (BSO), } \\
\text { TRX (auranofin) }\end{array}$ & $(107,108)$ \\
\hline & $\begin{array}{l}\text { Fatty acid } \\
\text { synthese }\end{array}$ & Cisplatin & FASN (orlistat) & $(110)$ \\
\hline & Glutaminolysis & $\begin{array}{l}\text { Cisplatin, } \\
\text { Paclitaxel }\end{array}$ & GLS (BPTES) & $(110,111)$ \\
\hline \multicolumn{5}{|c|}{ BREAST CANCER } \\
\hline & $\begin{array}{l}\text { Fatty acid } \\
\text { synthese }\end{array}$ & Adriamycin & FASN (Orlistat) & $(112)$ \\
\hline & $\begin{array}{l}\text { Redox } \\
\text { metabolism }\end{array}$ & Tamoxifen & GCLC (BSO) & $(75,113)$ \\
\hline & Glycolysis & $\begin{array}{l}\text { Lapatinib, } \\
\text { Paclitaxel, } \\
\text { Trastuzumab, } \\
\text { Tamoxifen }\end{array}$ & $\begin{array}{l}\text { HK (2-DG) } \\
\text { LDHA } \\
\text { (oxamate) }\end{array}$ & $\begin{array}{l}(52,114- \\
117)\end{array}$ \\
\hline & $\begin{array}{l}\text { Mitochondrial } \\
\text { energy } \\
\text { metabolism }\end{array}$ & $\begin{array}{l}\text { Lapatinib, } \\
\text { Tamoxifen }\end{array}$ & $\mathrm{ERR} \alpha, \mathrm{NQO1}$ & $\begin{array}{l}(113,118, \\
119)\end{array}$ \\
\hline
\end{tabular}

(Continued)
TABLE 1 | Continued

\begin{tabular}{|c|c|c|c|c|}
\hline $\begin{array}{l}\text { Cancer } \\
\text { type }\end{array}$ & $\begin{array}{l}\text { Pathways } \\
\text { associated } \\
\text { with } \\
\text { resistance }\end{array}$ & Therapy & $\begin{array}{l}\text { Target in } \\
\text { resistance } \\
\text { (proposed } \\
\text { therapy) }\end{array}$ & References \\
\hline \multicolumn{5}{|c|}{ MELANOMA } \\
\hline & $\begin{array}{l}\text { Mitochondrial } \\
\text { energy } \\
\text { metabolism }\end{array}$ & BRAF inhibitor & ETC (esclomol) & $(120-123)$ \\
\hline & Glutaminolysis & BRAF inhibitor & GLS (BPTES) & (120) \\
\hline & $\begin{array}{l}\text { Arginine } \\
\text { metabolism }\end{array}$ & BRAF inhibitor & $\begin{array}{l}\text { ASS1 (arginine } \\
\text { starvation) }\end{array}$ & $(124)$ \\
\hline & Glycolysis & $\begin{array}{l}\text { BRAF inhibitor } \\
\text { (Nemurafenib) }\end{array}$ & PDK1 (DCA) & $(121,125)$ \\
\hline & $\begin{array}{l}\text { Redox } \\
\text { Metabolism }\end{array}$ & $\begin{array}{l}\text { BRAF inhibitor } \\
\text { (Vemurafenib) }\end{array}$ & NAMPT & $(126)$ \\
\hline \multicolumn{5}{|c|}{ PANCREATIC CANCER } \\
\hline & Glycolysis & Gemcitabine & FBP1 & $(127,128)$ \\
\hline & $\begin{array}{l}\text { Fatty acid } \\
\text { synthesis }\end{array}$ & Gemcitabine & FASN (orlistat) & $(129,130)$ \\
\hline & Glutaminolysis & Gemcitabine & & (131) \\
\hline & $\begin{array}{l}\text { Redox } \\
\text { metabolism }\end{array}$ & Gemcitabine & xCT antiporter & (132) \\
\hline & $\begin{array}{l}\text { Pyrimidine } \\
\text { synthesis }\end{array}$ & Gemcitabine & $\begin{array}{l}\text { DODH } \\
\text { (leflunomide) }\end{array}$ & (128) \\
\hline \multicolumn{5}{|c|}{ LEUKEMIA } \\
\hline & Glycolysis & $\begin{array}{l}\text { Daunorubicin, } \\
\text { Imatinib }\end{array}$ & PFK2 & $(133,134)$ \\
\hline & $\begin{array}{l}\text { Mitochondrial } \\
\text { energy } \\
\text { metabolism }\end{array}$ & $\begin{array}{l}\text { Imatinib, } \\
\text { Cytarabine }\end{array}$ & - & $(135,136)$ \\
\hline \multicolumn{5}{|c|}{ HEPATOCELLULAR CARCINOMA } \\
\hline & Glutaminolysis & Sorefanib & $\begin{array}{l}\text { GLS1 } \\
\text { (BPTES), } \\
\text { PPAR } \delta\end{array}$ & $(137)$ \\
\hline \multicolumn{5}{|c|}{ SQUAMOUS CELL CARCINOMA } \\
\hline & Glycolysis & $\begin{array}{l}\text { Cisplatin, radiation } \\
\text { therapy }\end{array}$ & PKM2 & $(138,139)$ \\
\hline & $\begin{array}{l}\text { Redox } \\
\text { metabolism }\end{array}$ & $\begin{array}{l}\text { Cisplatin, radiation } \\
\text { therapy }\end{array}$ & & $(138,139)$ \\
\hline & $\begin{array}{l}\text { Nucleotide } \\
\text { metabolism }\end{array}$ & Gemcitabine & (metformin) & $(140)$ \\
\hline & $\begin{array}{l}\text { Fatty acid } \\
\text { synthesis }\end{array}$ & Radiation therapy & FASN (orlistat) & (139) \\
\hline \multicolumn{5}{|c|}{ COLON CANCER } \\
\hline & Glycolysis & $\begin{array}{l}\text { Multiple } \\
\text { chemotherapeutic } \\
\text { agents }\end{array}$ & & (141) \\
\hline \multicolumn{5}{|c|}{ ANAPLASTIC THYROID CANCER } \\
\hline & $\begin{array}{l}\text { Pentose } \\
\text { phosphate } \\
\text { pathway }\end{array}$ & Doxorubicin & 6PGD & $(142)$ \\
\hline
\end{tabular}

results in a disbalance between the production and degradation of proteins and eventually causes apoptosis in malignant cells via multiple pathways, including overproduction of ROS (145147). Although bortezomib therapy prolongs survival, some 
patients show intrinsic resistance to therapy, while others develop resistance during treatment $(21,147,148)$. Bortezomib resistance is associated with mutations in the proteasomal bortezomibbinding pocket and upregulation of the proteasomal machinery, both of which lower the efficacy of the drug (149-154). However, intracellular concentrations of bortezomib seem to correlate with proteasome inhibition, but not cytotoxicity (155). This suggests that adaptive resistance mechanisms are involved, which allow cells to proliferate even when proteasome function is impaired. Indeed, recent studies suggest that compensating mechanisms downstream of the proteasome are altered in bortezomib resistance, such as the unfolded protein response and vesicular exocytosis of ubiquitinated proteins (145, 156-159).

Several recent studies describe that metabolic processes are also involved in mediating sensitivity toward bortezomib (see Table 1, Figure 2A). In particular, pathways involved in energy metabolism and the anti-oxidant response are associated with bortezomib resistance (88-90, 92-95). For example, bortezomibresistant cells have higher mitochondrial function and expression of mitochondrial genes (94). Proteomic screening of bortezomibresistant and -sensitive cell lines also showed that resistant cells have increased levels of proteins involved in mitochondrial function and the generation of reducing equivalents (93). These increased levels of mitochondrial proteins are accompanied with higher activity of OXPHOS in proteasome inhibitor resistant cell lines (92). In addition, higher expression levels of genes related to OXPHOS were found in patients that responded poorly to bortezomib (92). Together, these studies suggest that bortezomib-resistant cells are more dependent on OXPHOS than -sensitive cells, making it a promising target for bortezomibresistance.

In addition, bortezomib-resistant cells have higher expression of superoxide dismutase 2 (SOD2) which is important for mitochondrial ROS clearing (94). The combination of SOD2 inhibition and bortezomib induces cell death in bortezomibresistant multiple myeloma cells via mitochondrial ROS overproduction (95). Because oxidative stress plays a role in the mechanism of action of bortezomib, it is likely that resistance is accompanied with increased antioxidant capacity. In line with this, high intracellular glutathione levels protect cells from bortezomib-induced apoptosis (96). Other antioxidant-related pathways are also upregulated in bortezomib-resistant cells, such as the PPP and SSP (91). High levels of PHGDH were found in bortezomib-resistant cells and starving multiple myeloma cell lines for serine during bortezomib treatment enhanced bortezomib toxicity (91). This demonstrates the importance of serine metabolism in bortezomib resistance.

Finally, several studies show that bortezomib resistance is accompanied with higher glycolytic activity (88, 89, 91, 93). Soriano et al. showed that proteasome inhibitor-resistant cells display higher levels of glycolytic enzymes and higher glycolytic rates than parental cell lines (93). Higher glycolytic activity has also been found to lower bortezomib sensitivity under hypoxic conditions, while inhibition of LDHA enhances sensitivity of bortezomib under these conditions (89). In addition, LDHA expression correlated to poor prognosis in multiple myeloma patients (88). Zaal et al. showed that bortezomib-resistant cells have a higher uptake of extracellular glucose, which is used for biosynthetic pathways branching off from glycolysis to support a higher anti-oxidant capacity (91). This is in line with findings that showed that dichloroacetate (DCA), which inhibits PDK1 and thereby promotes pyruvate entry into the TCA cycle, increases sensitivity of multiple myeloma cells to bortezomib both in vitro and in myeloma-bearing mice $(88,90)$.

\section{Metabolic Rewiring in Lung and Ovarian Cancer in Response to Cisplatin Treatment}

Cisplatin is a widely used chemotherapeutic agent in several types of cancer, including lung cancer and ovarian cancer. Cisplatin interacts with reducing equivalents (e.g., GSH) and DNA, resulting in increased ROS and DNA damage, which eventually leads to apoptosis (160). Many mechanisms involved in cisplatin resistance have been described, including reduced cisplatin uptake, increased DNA repair mechanisms and antiapoptotic pathways [reviewed in $(20,160)$ ]. Several studies suggest that metabolic rewiring in cisplatin-resistant cells is involved in redox buffering in both lung cancer and ovarian cancer cells to counteract cisplatin therapy (Table 1, Figure 2B) $(98,100,101,103,107)$. Cisplatin-resistant lung cancer cells have higher levels of ROS, in part due to low levels of intracellular thioredoxin (100), but display higher levels of GSH and GCLC $(20,103)$, likely to counteract the high ROS levels induced by cisplatin (161). Catanzaro et al. showed that cisplatin-resistant ovarian cancer cells have higher levels of GSH and G6PD and that PPP inhibition with 6-aminonicotinamide (6-AN) increases cisplatin cytotoxicity in these resistant cells $(107,109)$. In line with this, several studies show that cisplatin-resistant cells are vulnerable for ROS inducing agents. Cisplatin-resistant cells lung cancer cells have been reported to be more sensitive to elesclomol, an agent that is known to increase ROS (98). In addition, the xCTcysteine/glutamate pump that provides cells with cystine for GSH synthesis, is upregulated in these cisplatin-resistant cells, and they are more sensitive to the xCT-cysteine/glutamate pump inhibitor riluzole as compared to their parental counterpart (98). Also, inhibition of GSH biosynthesis with buthionine sulfoximine (BSO) enhances the effect of cisplatin in breast cancer cells (75).

Cisplatin-resistant cells have an altered energy metabolism compared to sensitive cells, but the findings on glycolysis and oxidative phosphorylation in lung and ovarian cancers are opposing. Cisplatin-resistant ovarian and cervical cancer cells were found to have higher rates of glycolysis and reduced mitochondrial activity compared to their cisplatin-sensitive counterparts. This leads to a higher sensitivity of resistant ovarian cancer cells to glucose starvation or to treatment with 2 deoxyglucose (2-DG), a competitive inhibitor of HK (107, 108). Cisplatin-resistant lung cancer cells, on the other hand, have lower rates of glycolysis and instead rely on oxidative phosphorylation $(98,99)$. These lung cancer cells have lower levels of HK1 and HK2 (99), in accordance with the observation that cisplatin treatment itself lowers HK expression (162). Cisplatin-resistant lung cancer cells also display lower glucose uptake and lower levels of LDHA and lactate production as compared to sensitive parental cell lines (98), all indicative of 


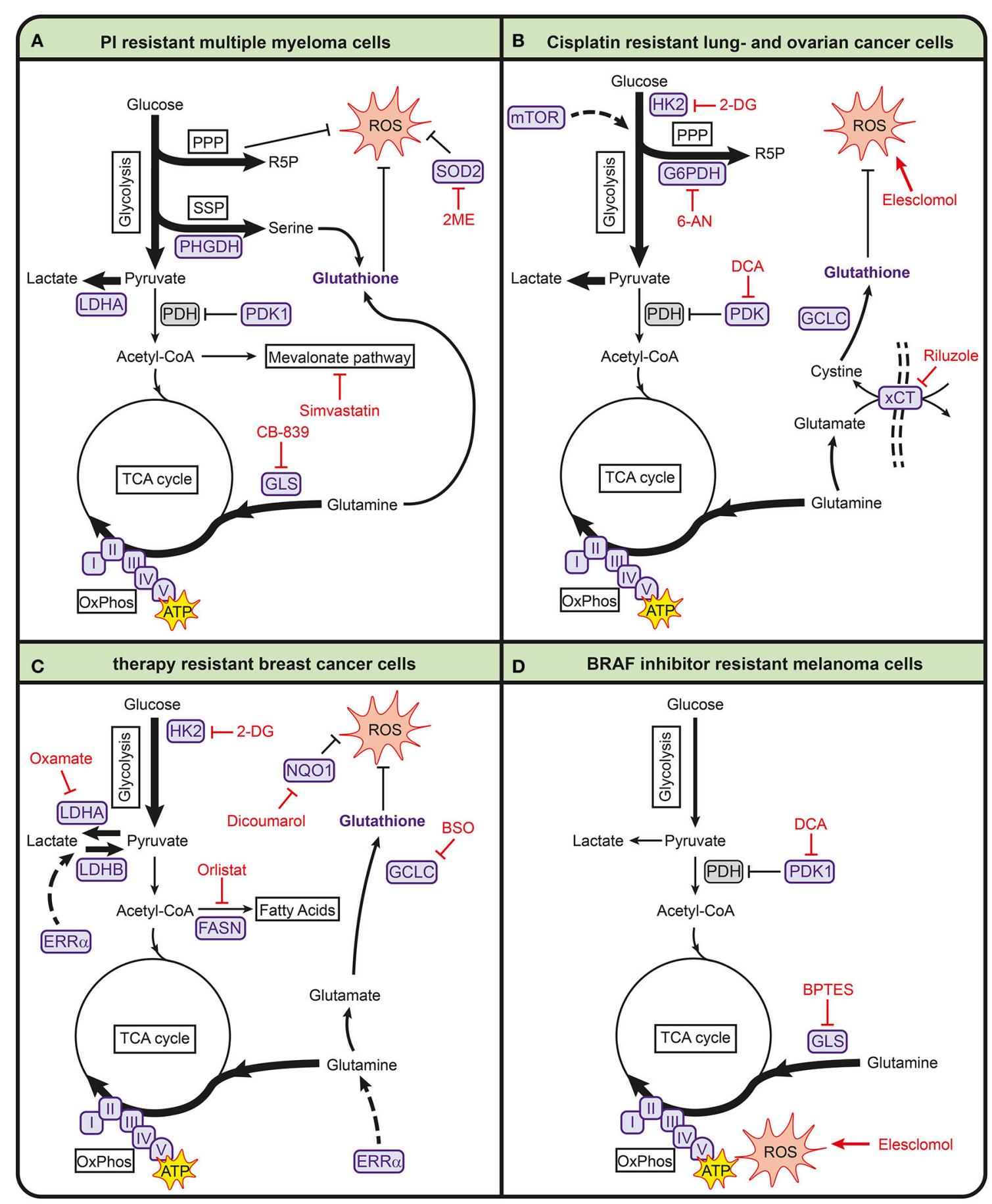

FIGURE 2 | Metabolic pathways involved in anticancer drug resistance in multiple myeloma (A), lung- and ovarian cancer (B), breast cancer (C), and melanoma (D). Metabolic enzymes that are associated with drug resistance are shown in purple. Metabolic inhibitors that can be used to target drug-resistant cancers are depicted in red. 2-DG, 2-deoxyglucose; 2ME, 2-methoxyestradiol; 6-AN, 6-aminonicotinamide; ATP, adenosine triphosphate; BPTES,

bis-2-(5-phenylacetamido-1,3,4-thiadiazol-2-yl)ethyl sulfide; BSO, buthionine sulphoximine; FASN, fatty acid synthase; G6PDH, glucose-6-phosphate dehydrogenase; GCLC, glutamate-cysteine ligase; GLS, glutaminase; HK2, hexokinase 2; I, complex I; II, complex II; III, complex III; IV, complex IV; LDHA, lactate dehydrogenase A; $\mathrm{LDHB}$, lactate dehydrogenase B; mTOR, mammalian target of rapamycin; NQO1, NAD(P)H quinone dehydrogenase; PDH, pyruvate dehydrogenase complex; PDK1, pyruvate dehydrogenase kinase 1; PHGDH, 3-phosphoglycerate dehydrogenase; PPP, pentose phosphate pathway; R5P, ribose 5-phosphate; ROS, reactive oxygen species; SOD2, superoxide dismutase 2; SSP, serine synthesis pathway; TCA, tricarboxylic acid cycle; V, complex V; xCT, glutamate/cysteine xCT antiporter. 
a lower glycolytic activity. In line with lower glycolysis rates, cisplatin-resistant lung cancer cells are not sensitive to glucose starvation under normal growth conditions. However, under hypoxic conditions, these cells are more vulnerable for 2-DG treatment as compared to the parental cells. As cells depend on glycolysis for their energy production in the absence of oxygen, the lower levels of $\mathrm{HK}$ in cisplatin-resistant cells likely makes them more vulnerable for 2-DG under these conditions (99). The lower glycolytic activity in cisplatin-resistant lung cancer cells is accompanied by higher rates of oxidative phosphorylation and mitochondrial activity (98-100), as well as a higher dependence on glutamine (98). Also $\beta$-oxidation of fatty acids has been described to fuel the TCA-cycle in cisplatin-resistant lung cancer cells $(99,100)$. In line with these findings, inhibition of glutaminase sensitized cisplatin-resistant ovarian cancers to chemotherapy $(110,111)$ and also the inhibition of FASN with orlistat enhanced the efficacy of cisplatin in ovarian cancers (110).

Interestingly, the metabolic reprogramming in lung cancer cells seems to some extent specific for cisplatin. Lung cancer cells that are resistant to carboplatin, which has a similar mode of action, are more dependent on glycolysis (106). In addition, paclitaxel-resistant lung cancer cells show higher expression of PDK2 as compared to their parental cells (105). As a result, these resistant cells are more dependent on glycolysis than OXPHOS and could be sensitized to paclitaxel through PDK2 inhibition. These examples highlight the heterogeneity of metabolic alterations in response to drugs and indicate that these can not only be tumor specific, but also drug specific.

\section{Metabolic Alterations Involved in Drug-Resistant Breast Cancers}

Many breast cancers overexpress the receptor tyrosine kinase ErbB2 and several drugs that target ErbB2, such as trastuzumab and lapatinib, are used in the treatment of breast cancer. Several mechanisms of resistance against these targeted therapies have been described, including the re-activation of downstream kinase pathways and oncogenic signaling $(112,163,164)$. In addition, metabolism pays a role in mediating resistance against tyrosine kinase inhibitors.

Increased glycolysis is a common feature of drug-resistant breast cancer cells irrespective of the type of chemotherapeutical agent used (Table 1, Figure 2c), but this increased activity is regulated in different ways in different resistant breast tumors. For example, several studies have found that resistance to lapatinib is associated with increased glycolysis (114, 115). Lapatinib-resistant SKBR3 breast cancer cells showed increased expression of genes associated with glucose deprivation compared to sensitive cells, which correlated to poor outcome in patients. These genes included glucose transporters and glycolytic enzymes, as well as alternative pathways for energy production, such as $\beta$-oxidation (114). Higher glycolytic activity and an increased sensitivity toward inhibition of glycolysis were also found in lapatinib-resistant BT474 breast cancer cells using a multi-omics approach involving (phospho)proteomics and metabolomics (115). Interestingly, the higher glycolytic rates in these BT474 cells were not resulting from higher expression levels of glycolytic enzymes, but merely from changes in the phosphorylation state of glycolytic enzymes, showing that post-translational modifications alone can regulate glycolytic activity. In trastuzumab-resistant ErbB2positive breast cancer cells, increased glycolytic activity is mediated by heat shock factor 1 and LDHA and inhibition of glycolysis with 2-DG and the $\mathrm{LDH}$ inhibitor oxamate resensitizes resistant cells to trastuzumab (117). Finally, in paclitaxel-resistant breast cancer cells, synergistic effects on promoting apoptosis were observed when LDHA was genetically downregulated or when paclitaxel was combined with oxamate (116).

Interestingly, Park et al. showed that the nuclear receptor estrogen-related receptor alpha $(\mathrm{ERR} \alpha)$ regulates a metabolic switch to allow breast cancer cells to use lactate as a substrate for mitochondrial respiration in the absence of glucose. The ability to bypass glycolysis makes these cells less vulnerable for $\mathrm{PI} 3 \mathrm{~K} / \mathrm{mTOR}$ inhibitors in the presence of lactate and ERR $\alpha$ antagonists are able to restore drug efficacy (119), underscoring the importance of nutrient availability drug efficacy. The importance of $\mathrm{ERR} \alpha$ in regulating metabolism is further emphasized by Deblois et al., who showed that lapatinib-resistant breast cancer cells restore ERR $\alpha$ levels through reactivation of mTOR signaling, resulting in increased glutamine metabolism, mitochondrial energy production and anti-oxidant capacity (118). Moreover, in a HER2-induced mammary tumor mouse model, targeting ERR $\alpha$ counteracts the metabolic alterations associated with lapatinib resistance and overcomes resistance to this drug (118). Targeting ERR $\alpha$ is therefore emerging as a strategy to increase the sensitivity of drug-resistant breast cancer cells in the context of metabolism.

Another metabolic aspect that is observed in drug-resistant breast cancer cells is increased levels of OXPHOS, coupled to higher levels of oxidative stress. For example, tamoxifen-resistant MCF-7 breast cancer cells display increased mitochondrial metabolism and ATP production (113). The biguanides metformin and phenformin, which inhibit ETC, selectively kill breast cancer stem cells that were resistant to standard chemotherapy (165), underscoring the importance of OXPHOS activity in drug response. This higher mitochondrial activity may also explain the observation that tamoxifen-resistant breast cancer cells display lower levels of GSH (113), as these cells probably experience higher levels of oxidative stress. In line with this, tamoxifen-resistant cells have higher expression of NADPH dehydrogenase 1 (NQO1) and GCLC, both involved in the defense against oxidative stress. Moreover, transduction of these genes into MCF-7 cells results in a tamoxifen-resistant phenotype and NQO1 mRNA levels associate with disease progression in patients that received endocrine therapy. As a result, NQO1 inhibition with dicoumarol restored tamoxifen sensitivity in tamoxifen-resistant breast cancer cells (113). Increased GSH synthesis was also observed in PI3K/Akt driven breast cancer and required for resistance to oxidative stress, Inhibition of GSH biosynthesis with BSO synergized with cisplatin to induce regression of in PI3K/Akt driven breast cancer (75). Together, these results suggest that an increased anti-oxidant defense 
mechanism drives resistance in breast cancer to various types of chemotherapy.

\section{Metabolic Contributions to BRAF Inhibitor Resistance in Melanoma}

Most cutaneous melanomas harbor activating mutations in the protein kinase BRAF, which makes inhibitors that target mutant BRAF promising agents to treat melanoma patients. In terms of metabolism, melanomas that express mutant BRAF and that developed resistance against BRAF inhibitors display increased activity of mitochondrial oxidative metabolism, increased dependency on mitochondria for survival and higher levels of ROS (Table 1, Figure 2D) (120-123, 126). For example, treatment of mutant BRAF melanoma cells with the BRAF inhibitor vemurafenib results in increased mitochondrial respiration. Inhibition of mitochondrial respiration enhances vemurafenib-induced cell death, suggesting that increased mitochondrial activity serves as a defense mechanism against the drug. At the same time, increased levels of ROS that accompany the increased respiration renders these cells more vulnerable for further oxidative stress induced by exogenous agents such as elesclomol (122). Baenke et al. showed that the increased dependency on mitochondrial respiration is associated with a metabolic switch that makes cells more dependent on glutamine rather than glucose. Hence, resistant BRAF mutant melanoma cells are more sensitive to the GLS inhibitor BPTES, which reduces ATP levels in resistant cells but not in parental cells. Moreover, BPTES enhances the anti-tumor activity of BRAF inhibitors, underscoring the importance of glutamine in mediating BRAF inhibitor resistance (120). A second metabolic switch in BRAF inhibitor-resistant melanoma cells was found on the level of PDK $(121,125)$. PDK inhibition reduced viability of BRAF inhibitor resistant cells, likely by increasing pyruvate influx into the TCA cycle and thereby mitochondrial ROS (121). The susceptibility to higher levels of oxidative stress was also observed in other tumor types that harbored a mutation in BRAF, as mutant BRAF colorectal cancer cells are prone to cell death after exposure to the oxidized form of vitamin $\mathrm{C}$, which causes oxidative stress via GSH depletion (166).

\section{TARGETING DRUG RESISTANCE THROUGH THE MANIPULATION OF METABOLISM}

From the studies discussed above, it becomes apparent that anticancer drug resistance to first-line chemotherapy is often linked to metabolic alterations and consequently, that these may be targeted to overcome drug resistance or to enhance the efficacy of current chemotherapy. Among the different drugresistant cancers described, pathways involved in redox and energy metabolism are frequently altered (Table 1, Figure 2), making them promising pathways to target drug-resistant cancers.

Resistance to several anticancer agents, including proteasome inhibitors, cisplatin, EGFR inhibitors and BRAF inhibitors, is accompanied with increased activity of pathways involved in redox balance, suggesting that interfering with redox metabolism can improve response to a wide range of drugs and aid in overcoming multidrug resistance. A majority of anticancer agents induce apoptosis by increasing oxidative stress $(96,101$, $132,137,167-169)$ and it is likely that drug-resistant cells in general increase their anti-oxidant capacity to counteract the effect of drug treatment, albeit via different pathways. But although an increased anti-oxidant capacity seems to be a common characteristic of drug-resistant cells, metabolic profiles are altered in drug-specific manners. For example, bortezomib- and sorafenib-resistant cells as well as cisplatinresistant ovarian cancers rely more on NADPH production via the PPP $(91,107,137)$, while tamoxifen-resistant cells and cisplatin-resistant lung cancers have higher activity of GSH synthesis $(75,103,113)$. The fact that several different pathways are involved suggests not only that a tailored approach may be needed to overcome resistance to specific drugs, but also that these redundant pathways may protect cancer cells to a large extent from inhibition of one specific pathway.

In addition, many studies show an association between drug resistant cells and the Warburg effect, suggesting that a high glycolytic rate helps cancer cells to survive anticancer treatment, such as bortezomib, cisplatin and lapatinib $(89,116,121,125$, 170 ). As a consequence, glycolytic inhibition with 2-deoxyglucose could be a novel strategy to overcome drug resistance. It has been postulated that higher glycolytic rates may lower drug efficacy through the increased secretion of lactate and acidification of the extracellular space, as some drugs are not stable under acidic conditions $(171,172)$. High glycolytic rates in drugresistant cells are often accompanied with higher expression of glycolytic regulators such as PDK1 and LDHA, making these enzymes interesting targets for drug-resistant cancers. In contrast, bortezomib- and BRAF inhibitor-resistant tumors rely more on mitochondrial activity fuelled by glutamine rather than glucose $(92,98,120)$. Interfering with glutamine metabolism, via either inhibition of glutaminolysis or glutamine uptake, could be a strategy for drug-resistant tumors that rely on glutamine (173, 174). In addition, as glutamine is mainly used for mitochondrial energy production, inhibition of the ETC with biguanides, such as metformin and phenformin, holds great promise in cancer therapy and drug resistance $(173,175)$.

Finally, most studies on metabolism-mediated drug resistance have so far focused on glycolysis and the TCA cycle and on the role glucose and glutamine. But fatty acids and branched chain amino acids can also provide energy and are also linked to tumorigenesis $(77,176)$. Interesting opportunities to target drug resistance may therefore also be found beyond glycolysis and the TCA cycle. FASN correlates with poor prognosis in various types of cancer and also interferes with drug efficacy (77). FASN overexpression causes resistance to the anticancer drugs adriamycin and mitoxantrone in breast cancer cells (112), gemcitabine-resistant pancreatic cells (129), cisplatin-resistant ovarian cancer cells (110), and radiotherapy resistant head and neck squamous cell carcinomas (139). Orlistat, a FASN inhibitor, increases the sensitivity to all drugs, suggesting that FASN can be a new target in drug resistant cancers. Amino acid metabolism 
may also yield promising targets to treat drug-resistant tumors. Cancer cells can be dependent on specific amino acids, such as serine $(58,177)$, proline $(74,178)$, aspartate $(65,73)$, and arginine (179). Although the role of amino acid metabolism in drug resistance is largely unexplored, studies suggest that amino acid availability could be important in drug response and the development of drug resistance. For example, BRAF inhibitor-resistant melanoma cells are more sensitive to arginine deprivation as compared to parental cells (124). Finally, serine synthesis is associated with bortezomib resistance in multiple myeloma and serine starvation enhanced the cytotoxic effect of bortezomib (91). These studies not only underscore the complexity of cancer metabolism, but also suggest that the exploration of amino acid metabolism may be a promising avenue to identify novel targets to overcome drug resistance.

\section{CONCLUSIONS}

It is clear that understanding cancer metabolism can improve cancer therapy, as exemplified by the widespread use of 18fluorodeoxyglucose, a glucose analog that exploits the Warburg effect in PET imaging for cancer diagnosis, treatment, and prognosis (180). The potential of metabolic inhibitors in cancer is also illustrated by the use of antimetabolites, such as 5fluorouracil and methotrexate, which have been used for decades to treat cancers (181), even though their anticancer effects were only coupled to metabolic interference much later (14). Another example of a successful metabolic drug is L-asparaginase, which is used in the treatment of acute lymphoblastic leukemia (182). The recent surge in knowledge in the field of cancer metabolism has sparked increased interest to exploit the altered metabolism

\section{REFERENCES}

1. Hanahan D, Weinberg RA. Hallmarks of cancer: the next generation. Cell (2011) 144:646-74. doi: 10.1016/j.cell.2011.02.013

2. Cairns RA, Harris IS, Mak TW. Regulation of cancer cell metabolism. Nat Rev Cancer (2011) 11:85-95. doi: 10.1038/nrc2981

3. Lunt SY, Fendt S-M. Metabolism - A cornerstone of cancer initiation, progression, immune evasion and treatment response. Curr Opin Syst Biol. (2017) 8:67-72. doi: 10.1016/j.coisb.2017.12.006

4. Vander Heiden MG, Cantley LC, Thompson CB. Understanding the Warburg effect: the metabolic requirements of cell proliferation. Science (2009) 324:1029-33. doi: 10.1126/science.1160809

5. Berkers CR, Maddocks ODK, Cheung EC, Mor I, Vousden KH. Metabolic regulation by p53 family members. Cell Metab. (2013) 18:617-33. doi: 10.1016/j.cmet.2013.06.019

6. Stine ZE, Walton ZE, Altman BJ, Hsieh AL, Dang CV. MYC, Metabolism, and Cancer. Cancer Discov. (2015) 5:1024-39. doi: 10.1158/2159-8290.CD-15-0507

7. Herzig S, Shaw RJ. AMPK: guardian of metabolism and mitochondrial homeostasis. Nat Rev Mol Cell Biol. (2017) 19:121-35. doi: $10.1038 / \mathrm{nrm} .2017 .95$

8. Lien EC, Lyssiotis CA, Cantley LC. Metabolic reprogramming by the PI3KAkt-mTOR pathway in cancer. In: Cramer T, Schmitt CA editors. Metabolism in Cancer. Cham: Springer International Publishing. (2016). p. 39-72.

9. Semenza GL. HIF-1: upstream and downstream of cancer metabolism. Curr Opin Genet Dev. (2010) 20:51-6. doi: 10.1016/j.gde.2009. 10.009 of cancer cells to find novel targets for therapy. As a result, compounds have been developed that specifically target the unique metabolism of cancers. Several of these compounds targeting for example glycolysis, TCA cycle and OXPHOS are now being tested in clinical trials $(13,14,160,183)$.

In this review, we discussed specific metabolic programs and adaptations that exist in drug-resistant tumors, how these adaptations depend both on the drug and the origin of the tumor and how they contribute to drug resistance. From these studies, it becomes apparent that for many first-line chemotherapeutic agents, combinational treatments with metabolic drugs hold great promise to increase drug efficacy. Moreover, a better understanding of the altered metabolism in different drug resistant cancers is essential to further improve cancer therapy. Such understanding will provide insights into the molecular mechanisms of resistance to identify novel metabolic targets that can be used for (combinational) therapy. Finally, this knowledge may also lead to prognostic biomarkers for drug response, which could advance current therapy by predicting drug response based on the metabolic state of a tumor and thereby contribute toward more efficacious personalized medicine.

\section{AUTHOR CONTRIBUTIONS}

$\mathrm{CB}$ and EZ wrote the manuscript. Both authors read and approved the final version of the manuscript.

\section{FUNDING}

CB was supported by VENI grant (project 722.013.009) from the Netherlands Organization for Scientific Research (NWO).

10. Kawada K, Toda K, Sakai Y. Targeting metabolic reprogramming in KRAS-driven cancers. Int J Clin Oncol. (2017) 22:651-9. doi: 10.1007/s10147-017-1156-4

11. Plas DR, Thompson CB. Akt-dependent transformation: there is more to growth than just surviving. Oncogene (2005) 24:7435-42. doi: 10.1038/sj.onc.1209097

12. Lyssiotis CA, Kimmelman AC. Metabolic interactions in the tumor microenvironment. Trends Cell Biol. (2017) 27:863-75. doi: 10.1016/j.tcb.2017.06.003

13. Tennant DA, Durán RV, Gottlieb E. Targeting metabolic transformation for cancer therapy. Nat Rev Cancer (2010) 10:267-77. doi: 10.1038/nrc2817

14. Vander Heiden MG. Targeting cancer metabolism: a therapeutic window opens. Nat Rev Drug Discov. (2011) 10:671-84. doi: 10.1038/nrd3504

15. Longley DB, Johnston PG. Molecular mechanisms of drug resistance. $J$ Pathol. (2005) 205:275-92. doi: 10.1002/path.1706

16. Holohan C, Van Schaeybroeck S, Longley DB, Johnston PG. Cancer drug resistance: an evolving paradigm. Nat Rev Cancer (2013) 13:714-26. doi: $10.1038 / \mathrm{nrc} 3599$

17. Groenendijk FH, Bernards RE. Drug resistance to targeted therapies: D ej a vu all over again. Mol Oncol. (2014) 8:1067-83. doi: 10.1016/j.molonc.2014.05.004

18. Housman G, Byler S, Heerboth S, Lapinska K, Longacre M, Snyder N, et al. Drug resistance in cancer: an overview. Cancers (2014) 6:1769-92. doi: 10.3390/cancers6031769

19. Kirschner K, Melton DW. Multiple roles of the ERCC1-XPF endonuclease in DNA repair and resistance to anticancer drugs. Anticancer Res. (2010) 30:3223-32. 
20. Jain A, Jahagirdar D, Nilendu P, Sharma NK. Molecular approaches to potentiate cisplatin responsiveness in carcinoma therapeutics. Expert Rev Anticancer Ther. (2017) 17:815-25. doi: 10.1080/14737140.2017.1356231

21. McConkey DJ, Zhu K. Mechanisms of proteasome inhibitor action and resistance in cancer. Drug Resist Updat. (2008) 11:164-79. doi: 10.1016/j.drup.2008.08.002

22. Hu Y-L, DeLay M, Jahangiri A, Molinaro AM, Rose SD, Carbonell WS, et al. Hypoxia-induced autophagy promotes tumor cell survival and adaptation to antiangiogenic treatment in glioblastoma. Cancer Res. (2012) 72:1773-83. doi: 10.1158/0008-5472.CAN-11-3831

23. Engelman JA, Zejnullahu K, Mitsudomi T, Song Y, Hyland C, Park JO, et al. MET amplification leads to gefitinib resistance in lung cancer by activating ERBB3 signaling. Science (2007) 316:1039-43. doi: 10.1126/science.1141478

24. Nazarian R, Shi H, Wang Q, Kong X, Koya RC, Lee H, et al. Melanomas acquire resistance to $\mathrm{B}-\mathrm{RAF}(\mathrm{V} 600 \mathrm{E})$ inhibition by RTK or N-RAS upregulation. Nature (2010) 468:973-7. doi: 10.1038/nature09626

25. Wagle N, Emery C, Berger MF, Davis MJ, Sawyer A, Pochanard P, et al. Dissecting therapeutic resistance to RAF inhibition in melanoma by tumor genomic profiling. J Clin Oncol. (2011) 29:3085-96. doi: $10.1200 /$ JCO.2010.33.2312

26. Johannessen CM, Boehm JS, Kim SY, Thomas SR, Wardwell L, Johnson LA, et al. COT drives resistance to RAF inhibition through MAP kinase pathway reactivation. Nature (2010) 468:968-72. doi: 10.1038/nature09627

27. Swanton C. Intratumor heterogeneity: evolution through space and time. Cancer Res. (2012) 72:4875-82. doi: 10.1158/0008-5472.CAN-12-2217

28. Nicholls DG, Budd SL. Mitochondria and neuronal survival. Physiol Rev. (2000) 80:315-60. doi: 10.1152/physrev.2000.80.1.315

29. Pavlova NN, Thompson CB. The emerging hallmarks of cancer metabolism. Cell Metab. (2016) 23:27-47. doi: 10.1016/j.cmet.2015.12.006

30. Warburg O. On the origin of cancer cells. Science (1956) 123:309-314. doi: 10.1126/science.123.3191.309

31. Yamamoto $T$, Seino $Y$, Fukumoto $H$, Koh $G$, Yano $H$, Inagaki $N$, et al. Over-expression of facilitative glucose transporter genes in human cancer. Biochem Biophys Res Commun. (1990) 170:223-30. doi: 10.1016/0006-291X(90)91263-R

32. Macheda ML, Rogers S, Best JD. Molecular and cellular regulation of glucose transporter (GLUT) proteins in cancer. J Cell Physiol. (2005) 202:654-62. doi: $10.1002 /$ jcp. 20166

33. Lee JY, Lee I, Chang WJ, Ahn SM, Lim SH, Kim HS, et al. MCT4 as a potential therapeutic target for metastatic gastric cancer with peritoneal carcinomatosis. Oncotarget (2016) 7:43492-503. doi: 10.18632/oncotarget.9523

34. Baek GH, Tse YF, Hu Z, Cox D, Buboltz N, McCue $\mathrm{P}$, et al. MCT4 defines a glycolytic subtype of pancreatic cancer with poor prognosis and unique metabolic dependencies. Cell Rep. (2014) 9:2233-49. doi: 10.1016/j.celrep.2014.11.025

35. Fischer K, Hoffmann P, Voelkl S, Meidenbauer N, Ammer J, Edinger M, et al. Inhibitory effect of tumor cell-derived lactic acid on human $\mathrm{T}$ cells. Blood (2015) 109:3812-20. doi: 10.1182/blood-2006-07-035972

36. Goetze K, Walenta S, Ksiazkiewicz M, Kunz-Schughart LA, MuellerKlieser W. Lactate enhances motility of tumor cells and inhibits monocyte migration and cytokine release. Int J Oncol. (2011) 39:453-63. doi: 10.3892/ijo.2011.1055

37. Mazurek S. Pyruvate kinase type M2: a key regulator of the metabolic budget system in tumor cells. Int J Biochem Cell Biol. (2011) 43:969-80. doi: 10.1016/j.biocel.2010.02.005

38. Liu VM, Vander Heiden MG. The role of pyruvate kinase M2 in cancer metabolism. Brain Pathol. (2015) 25:781-3. doi: 10.1111/bpa.12311

39. Shinohara Y, Yamamoto K, Kogure K, Ichihara J, Terada H. Steady state transcript levels of the type II hexokinase and type 1 glucose transporter in human tumor cell lines. Cancer Lett. (1994) 82:27-32. doi: 10.1016/0304-3835(94)90142-2

40. Wolf A, Agnihotri S, Micallef J, Mukherjee J, Sabha N, Cairns R, et al. Hexokinase 2 is a key mediator of aerobic glycolysis and promotes tumor growth in human glioblastoma multiforme. J Exp Med. (2011) 208:313-26. doi: 10.1084/jem.20101470

41. Fantin VR, St-Pierre J, Leder P. Attenuation of LDH-A expression uncovers a link between glycolysis, mitochondrial physiology, and tumor maintenance. Cancer Cell (2006) 9:425-34. doi: 10.1016/j.ccr.2006 04.023

42. Ren F, Wu H, Lei Y, Zhang H, Liu R, Zhao Y, et al. Quantitative proteomics identification of phosphoglycerate mutase 1 as a novel therapeutic target in hepatocellular carcinoma. Mol Cancer (2010) 9:81. doi: 10.1186/1476-4598-9-81

43. Chaneton B, Gottlieb E. PGAMgnam style: a glycolytic switch controls biosynthesis. Cancer Cell (2012) 22:565-6. doi: 10.1016/j.ccr.2012.10.014

44. Kim J, Tchernyshyov I, Semenza GL, Dang CV. HIF-1-mediated expression of pyruvate dehydrogenase kinase: a metabolic switch required for cellular adaptation to hypoxia. Cell Metab. (2006) 3:177-85. doi: 10.1016/j.cmet.2006.02.002

45. Atsumi T, Chesney J, Metz C, Leng L, Donnelly S, Makita Z, et al. High expression of inducible 6-phosphofructo-2-kinase/fructose-2,6bisphosphatase (iPFK-2; PFKFB3) in human cancers. Cancer Res. (2002) 62:5881-7.

46. Yalcin A, Telang S, Clem B, Chesney J. Regulation of glucose metabolism by 6-phosphofructo-2-kinase/fructose-2,6-bisphosphatases in cancer. Exp Mol Pathol. (2009) 86:174-9. doi: 10.1016/j.yexmp.2009.01.003

47. Anderson NM, Mucka P, Kern JG, Feng H. The emerging role and targetability of the TCA cycle in cancer metabolism. Protein Cell (2017) 9:216-37. doi: 10.1007/s13238-017-0451-1

48. Yang M, Soga T, Pollard PJ. Oncometabolites: Linking altered metabolism with cancer. J Clin Invest. (2013) 123:3652-8. doi: 10.1172/JCI67228

49. DeBerardinis RJ, Chandel NS. Fundamentals of cancer metabolism. Sci Adv. (2016) 2:e1600200. doi: 10.1126/sciadv.1600200

50. Frezza C, Gottlieb E. Mitochondria in cancer: not just innocent bystanders. Semin Cancer Biol. (2009) 19:4-11. doi: 10.1016/j.semcancer.2008.11.008

51. Benito A, Polat IH, No,é V, Ciudad CJ, Marin S, Cascante M. Glucose6-phosphate dehydrogenase and transketolase modulate breast cancer cell metabolic reprogramming and correlate with poor patient outcome. Oncotarget (2017) 8:106693-706. doi: 10.18632/oncotarget.21601

52. Ambrosio MR, D’Esposito V, Costa V, Liguoro D, Collina F, Cantile M, et al. Glucose impairs tamoxifen responsiveness modulating connective tissue growth factor in breast cancer cells. Oncotarget (2017) 8:109000-17. doi: 10.18632/oncotarget.22552

53. Patra KC, Hay N. The pentose phosphate pathway and cancer. Trends Biochem Sci. (2014) 39:347-54. doi: 10.1016/j.tibs.2014.06.005

54. Kowalik MA, Columbano A, Perra A. Emerging role of the pentose phosphate pathway in hepatocellular carcinoma. Front Oncol. (2017) 7:87. doi: $10.3389 /$ fonc. 2017.00087

55. Maddocks ODK, Labuschagne CF, Adams PD, Vousden KH. Serine metabolism supports the methionine cycle and DNA/RNA methylation through de novo ATP synthesis in cancer cells. Mol Cell (2016) 61:210-21. doi: 10.1016/j.molcel.2015.12.014

56. Labuschagne CF, van den Broek NJF, Mackay GM, Vousden KH, Maddocks ODK. Serine, but not glycine, supports one-carbon metabolism and proliferation of cancer cells. Cell Rep. (2014) 7:1248-58. doi: 10.1016/j.celrep.2014.04.045

57. Locasale JW, Grassian AR, Melman T, Lyssiotis CA, Mattaini KR, Bass AJ, et al. Phosphoglycerate dehydrogenase diverts glycolytic flux and contributes to oncogenesis. Nat Genet. (2011) 43:869-74. doi: 10.1038/ng.890

58. Possemato R, Marks KM, Shaul YD, Pacold ME, Kim D, Birsoy K, et al. Functional genomics reveal that the serine synthesis pathway is essential in breast cancer. Nature (2011) 476:346-50. doi: 10.1038/nature 10350

59. Chaneton B, Hillmann P, Zheng L, Martin ACL, Maddocks ODK, Chokkathukalam A, et al. Serine is a natural ligand and allosteric activator of pyruvate kinase M2. Nature (2012) 491:458-62. doi: 10.1038/nature11540

60. Ye J, Mancuso A, Tong X, Ward PS, Fan J, Rabinowitz JD, et al. Pyruvate kinase M2 promotes de novo serine synthesis to sustain mTORC1 activity and cell proliferation. Proc Natl Acad Sci USA. (2012) 109:6904-9. doi: 10.1073/pnas.1204176109

61. Anastasiou D, Yu Y, Israelsen WJ, Jiang J-K, Boxer MB, Hong BS, et al. Pyruvate kinase M2 activators promote tetramer formation and suppress tumorigenesis. Nat Chem Biol. (2012) 8:839-47. doi: 10.1038/nchembio.1060

62. Kuehne A, Emmert H, Soehle J, Winnefeld M, Fischer F, Wenck H, et al. Acute activation of oxidative pentose phosphate pathway as first-line 
response to oxidative stress in human skin cells. Mol Cell (2015) 59:359-71. doi: 10.1016/j.molcel.2015.06.017

63. Hitosugi T, Zhou L, Elf S, Fan J, Kang H-B, Seo JH, et al. Phosphoglycerate mutase 1 coordinates glycolysis and biosynthesis to promote tumor growth. Cancer Cell (2012) 22:585-600. doi: 10.1016/j.ccr.2012.09.020

64. Röhrig F, Schulze A. The multifaceted roles of fatty acid synthesis in cancer. Nat Rev Cancer (2016) 16:732-49. doi: 10.1038/nrc.2016.89

65. Sullivan LB, Gui DY, Hosios AM, Bush LN, Freinkman E, Vander Heiden MG. Supporting aspartate biosynthesis is an essential function of respiration in proliferating Cells. Cell (2015) 162:552-63. doi: 10.1016/j.cell.2015.07.017

66. DeBerardinis RJ, Mancuso A, Daikhin E, Nissim I, Yudkoff M, Wehrli $S$, et al. Beyond aerobic glycolysis: transformed cells can engage in glutamine metabolism that exceeds the requirement for protein and nucleotide synthesis. Proc Natl Acad Sci USA. (2007) 104:19345-50. doi: 10.1073/pnas.0709747104

67. Eagle H. Nutrition needs of mammalian cells in tissue culture. Science (1955) 122:501-14. doi: 10.1126/science.122.3168.501

68. Reitzer LJ, Wice BM, Kennell D. Evidence that glutamine, not sugar, is the major energy source for cultured HeLa cells. J Biol Chem. (1979) 254:266976.

69. Hosios AM, Hecht VC, Danai LV, Johnson MO, Rathmell JC, Steinhauser $\mathrm{ML}$, et al. Amino acids rather than glucose account for the majority of cell mass in proliferating mammalian cells. Dev Cell (2016) 36:540-9. doi: 10.1016/j.devcel.2016.02.012

70. Swamy M, Pathak S, Grzes KM, Damerow S, Sinclair LV, van Aalten $\mathrm{DMF}$, et al. Glucose and glutamine fuel protein O-GlcNAcylation to control T cell self-renewal and malignancy. Nat Immunol. (2016) 17:712-20. doi: 10.1038/ni.3439

71. Wise DR, DeBerardinis RJ, Mancuso A, Sayed N, Zhang X-Y, Pfeiffer HK, et al. Myc regulates a transcriptional program that stimulates mitochondrial glutaminolysis and leads to glutamine addiction. Proc Natl Acad Sci USA. (2008) 105:18782-7. doi: 10.1073/pnas.0810199105

72. Gao P, Tchernyshyov I, Chang T-C, Lee Y-S, Kita K, Ochi T, et al. cMyc suppression of $\mathrm{miR}-23 \mathrm{a} / \mathrm{b}$ enhances mitochondrial glutaminase expression and glutamine metabolism. Nature (2009) 458:762-5. doi: $10.1038 /$ nature 07823

73. Birsoy K, Wang T, Chen WW, Freinkman E, Abu-Remaileh M, Sabatini DM. An essential role of the mitochondrial electron transport chain in cell proliferation is to enable aspartate synthesis. Cell (2015) 162:540-51. doi: 10.1016/j.cell.2015.07.016

74. Loayza-Puch F, Rooijers K, Buil LCM, Zijlstra J, Oude Vrielink JF, Lopes $\mathrm{R}$, et al. Tumour-specific proline vulnerability uncovered by differential ribosome codon reading. Nature (2016) 530:490-4. doi: 10.1038/nature16982

75. Lien EC, Lyssiotis CA, Juvekar A, Hu H, Asara JM, Cantley LC, et al. Glutathione biosynthesis is a metabolic vulnerability in PI(3)K/Akt-driven breast cancer. Nat Cell Biol. (2016) 18:572-8. doi: 10.1038/ncb3341

76. Beatty A, Fink LS, Singh T, Strigun A, Peter E, Ferrer CM, et al. Metabolite profiling reveals the glutathione biosynthetic pathway as a therapeutic target in triple negative breast cancer. Mol. Cancer Ther. (2017) 17:264-75. doi: 10.1158/1535-7163.MCT-17-0407

77. Carracedo A, Cantley LC, Pandolfi PP. Cancer metabolism: fatty acid oxidation in the limelight. Nat Rev Cancer (2013) 13:227-32. doi: $10.1038 / \mathrm{nrc} 3483$

78. Zaugg K, Yao Y, Reilly PT, Kannan K, Kiarash R, Mason J, et al. Carnitine palmitoyltransferase $1 \mathrm{C}$ promotes cell survival and tumor growth under conditions of metabolic stress. Genes Dev. (2011) 25:1041-51. doi: 10.1101/gad.1987211

79. Hui S, Ghergurovich JM, Morscher RJ, Jang C, Teng X, Lu W, et al. Glucose feeds the TCA cycle via circulating lactate. Nature (2017) 551:115-8. doi: 10.1038/nature24057

80. Mashimo T, Pichumani K, Vemireddy V, Hatanpaa KJ, Singh DK, Sirasanagandla $S$, et al. Acetate is a bioenergetic substrate for human glioblastoma and brain metastases. Cell (2014) 159:1603-14. doi: 10.1016/j.cell.2014.11.025

81. Green CR, Wallace M, Divakaruni AS, Phillips SA, Murphy AN, Ciaraldi $\mathrm{TP}$, et al. Branched-chain amino acid catabolism fuels adipocyte differentiation and lipogenesis. Nat Chem Biol. (2016) 12:15-21. doi: $10.1038 /$ nchembio. 1961
82. King A, Selak MA, Gottlieb E. Succinate dehydrogenase and fumarate hydratase: Linking mitochondrial dysfunction and cancer. Oncogene (2006) 25:4675-82. doi: 10.1038/sj.onc.1209594

83. Selak MA, Armour SM, MacKenzie ED, Boulahbel H, Watson DG, Mansfield KD, et al. Succinate links TCA cycle dysfunction to oncogenesis by inhibiting HIF- $\alpha$ prolyl hydroxylase. Cancer Cell (2005) 7:77-85. doi: 10.1016/j.ccr.2004.11.022

84. Sciacovelli M, Frezza C. Oncometabolites: unconventional triggers of oncogenic signalling cascades. Free Radic Biol Med. (2016) 100:175-81. doi: 10.1016/j.freeradbiomed.2016.04.025

85. Parsons DW, Jones S, Zhang X, Lin JC, Leary RJ, Angenendt P, et al. An integrated genomic analysis of human glioblastoma multiforme. Science (2008) 321:1807-12. doi: 10.1126/science.1164382

86. Yan H, Parsons DW, Jin G, McLendon R, Rasheed BA, Yuan W, et al. IDH1 and IDH2 mutations in gliomas. N Engl J Med. (2009) 360:765-73. doi: 10.1056/NEJMoa0808710

87. Dang L, White DW, Gross S, Bennett BD, Bittinger MA, Driggers EM, et al. Cancer-associated IDH1 mutations produce 2-hydroxyglutarate. Nature (2009) 462:739-44. doi: 10.1038/nature08617

88. Fujiwara S, Kawano Y, Yuki H, Okuno Y, Nosaka K, Mitsuya H, et al. PDK1 inhibition is a novel therapeutic target in multiple myeloma. Br J Cancer (2013) 108:170-8. doi: 10.1038/bjc.2012.527

89. Maiso P, Huynh D, Moschetta M, Sacco A, Aljawai Y, Mishima $\mathrm{Y}$, et al. Metabolic signature identifies novel targets for drug resistance in multiple myeloma. Cancer Res. (2015) 75:2071-82. doi: 10.1158/0008-5472.CAN-14-3400

90. Sanchez WY, McGee SL, Connor T, Mottram B, Wilkinson A, Whitehead JP, et al. Dichloroacetate inhibits aerobic glycolysis in multiple myeloma cells and increases sensitivity to bortezomib. Br J Cancer (2013) 108:1624-33. doi: 10.1038/bjc.2013.120

91. Zaal EA, Wu W, Jansen G, Zweegman S, Cloos J, Berkers CR. Bortezomib resistance in multiple myeloma is associated with increased serine synthesis. Cancer Metab. (2017) 5:7. doi: 10.1186/s40170-017-0169-9

92. Thompson RM, Dytfeld D, Reyes L, Robinson RM, Smith B, Manevich Y, et al. Glutaminase inhibitor CB-839 synergizes with carfilzomib in resistant multiple myeloma cells. (2017) 8:35863-76. doi: 10.18632/oncotarget.16262

93. Soriano GP, Besse L, Li N, Kraus M, Besse A, Meeuwenoord N, et al. Proteasome inhibitor-adapted myeloma cells are largely independent from proteasome activity and show complex proteomic changes, in particular in redox and energy metabolism. Leukemia (2016) 30:2198-207. doi: 10.1038/leu.2016.102

94. Song IS, Kim HK, Lee SR, Jeong SH, Kim N, Ko KS, et al. Mitochondrial modulation decreases the bortezomib-resistance in multiple myeloma cells. Int J cancer (2013) 133:1357-67. doi: 10.1002/ijc.28149

95. Song I-S, Jeong YJ, Jeong SH, Heo HJ, Kim HK, Lee SR, et al. Combination treatment with 2-methoxyestradiol overcomes bortezomib resistance of multiple myeloma cells. Exp Mol Med. (2013) 45:e50. doi: 10.1038/emm.2013.104

96. Du Z-X, Zhang H-Y, Meng X, Guan Y, Wang H-Q. Role of oxidative stress and intracellular glutathione in the sensitivity to apoptosis induced by proteasome inhibitor in thyroid cancer cells. BMC Cancer (2009) 9:56. doi: 10.1186/1471-2407-9-56

97. Fuchs D, Berges C, Opelz G, Daniel V, Naujokat C. HMG-CoA reductase inhibitor simvastatin overcomes bortezomib-induced apoptosis resistance by disrupting a geranylgeranyl pyrophosphate-dependent survival pathway. Biochem Biophys Res Commun. (2008) 374:309-14. doi: 10.1016/j.bbrc.2008.07.012

98. Wangpaichitr M, Wu C, Li YY, Nguyen DJM, Kandemir H, Shah S, et al. Exploiting ROS and metabolic differences to kill cisplatin resistant lung cancer. Oncotarget (2017) 8:49275-92. doi: 10.18632/oncotarget.17568

99. Sullivan EJ, Kurtoglu M, Brenneman R, Liu H, Lampidis TJ. Targeting cisplatin-resistant human tumor cells with metabolic inhibitors. Cancer Chemother Pharmacol. (2014) 73:417-27. doi: 10.1007/s00280-0132366-8

100. Wangpaichitr M, Sullivan EJ, Theodoropoulos G, Wu C, You M, Feun LG, et al. The relationship of thioredoxin- 1 and cisplatin resistance: its impact on ROS and oxidative metabolism in lung cancer cells. Mol Cancer Ther. (2012) 11:604-15. doi: 10.1158/1535-7163.MCT-11-0599 
101. Marullo R, Werner E, Degtyareva N, Moore B, Altavilla G, Ramalingam SS, et al. Cisplatin induces a mitochondrial-ROS response that contributes to cytotoxicity depending on mitochondrial redox status and bioenergetic functions. PLoS ONE (2013) 8:e81162. doi: 10.1371/journal.pone.0081162

102. Wangpaichitr M, Wu C, You M, Maher JC, Dinh V, Feun LG, et al. N'N'Dimethyl-N',N'-bis(phenylcarbonothioyl) propanedihydrazide (elesclomol) selectively kills cisplatin resistant lung cancer cells through reactive oxygen species (ROS). Cancers (2009) 1:23-38. doi: 10.3390/cancers1010023

103. Galluzzi L, Senovilla L, Vitale I, Michels J, Martins I, Kepp O, et al. Molecular mechanisms of cisplatin resistance. Oncogene (2012) 31:1869-83. doi: 10.1038/onc.2011.384

104. Wu C, Wangpaichitr M, Feun L, Kuo MT, Robles C, Lampidis T, et al. Overcoming cisplatin resistance by mTOR inhibitor in lung cancer. $\mathrm{Mol}$ Cancer (2005) 4:25. doi: 10.1186/1476-4598-4-25

105. Sun H, Zhu A, Zhou X, Wang F. Suppression of pyruvate dehydrogenase kinase-2 re-sensitizes paclitaxel-resistant human lung cancer cells to paclitaxel. Oncotarget (2017) 5:1-9. doi: 10.18632/oncotarget.16991

106. Liu Y, He C, Huang X. Metformin partially reverses the carboplatinresistance in NSCLC by inhibiting glucose metabolism. Oncotarget (2017) 8:75206-16. doi: 10.18632/oncotarget.20663

107. Catanzaro D, Gaude E, Orso G, Giordano C, Guzzo G, Rasola A, et al. Inhibition of glucose-6-phosphate dehydrogenase sensitizes cisplatin-resistant cells to death. Oncotarget (2015) 6:30102-14. doi: 10.18632/oncotarget.4945

108. Rashmi R, Huang X, Floberg JM, Elhammali AE, McCormick ML, Patti GJ, et al. Radioresistant cervical cancers are sensitive to inhibition of glycolysis and redox metabolism. Cancer Res. (2018) 78:1392-403. doi: 10.1158/0008-5472.CAN-17-2367

109. Catanzaro D, Nicolosi S, Cocetta V, Salvalaio M, Pagetta A, Ragazzi E, et al. Cisplatin liposome and 6-amino nicotinamide combination to overcome drug resistance in ovarian cancer cells. Oncotarget (2018) 9:16847-60. doi: 10.18632/oncotarget.24708

110. Papaevangelou E, Almeida GS, Box C, DeSouza NM, Chung YL. The effect of FASN inhibition on the growth and metabolism of a cisplatinresistant ovarian carcinoma model. Int J Cancer. (2018) 143:992-1002. doi: $10.1002 /$ ijc.31392

111. Masamha CP, LaFontaine P. Molecular targeting of glutaminase sensitizes ovarian cancer cells to chemotherapy. J Cell Biochem. (2018) 119:6136-45. doi: $10.1002 /$ jcb.26814

112. Liu H, Liu Y, Zhang J-T. A new mechanism of drug resistance in breast cancer cells: fatty acid synthase overexpression-mediated palmitate overproduction. Mol Cancer Ther. (2008) 7:263-70. doi: 10.1158/1535-7163.MCT-07-0445

113. Fiorillo M, Sotgia F, Sisci D, Cappello AR, Lisanti MP. Mitochondrial "power" drives tamoxifen resistance: NQO1 and GCLC are new therapeutic targets in breast cancer. Oncotarget (2017) 8:20309-27. doi: 10.18632/oncotarget.15852

114. Komurov K, Tseng J-T, Muller M, Seviour EG, Moss TJ, Yang L, et al. The glucose-deprivation network counteracts lapatinib-induced toxicity in resistant ErbB2-positive breast cancer cells. Mol Syst Biol. (2012) 8:596. doi: $10.1038 / \mathrm{msb} .2012 .25$

115. Ruprecht B, Zaal EA, Zecha J, Wu W, Berkers CR, Kuster B, et al. Lapatinib resistance in breast cancer cells is accompanied by phosphorylationmediated reprogramming of glycolysis. Cancer Res. (2017) 77:1842-53. doi: 10.1158/0008-5472.CAN-16-2976

116. Zhou M, Zhao Y, Ding Y, Liu H, Liu Z, Fodstad O, et al. Warburg effect in chemosensitivity: targeting lactate dehydrogenase-A resensitizes taxol-resistant cancer cells to taxol. Mol Cancer (2010) 9:33. doi: 10.1186/1476-4598-9-33

117. Zhao Y, Liu H, Liu Z, Ding Y, Ledoux SP, Wilson GL, et al. Overcoming trastuzumab resistance in breast cancer by targeting dysregulated glucose metabolism. Cancer Res. (2011) 71:4585-97. doi: 10.1158/0008-5472.CAN-11-0127

118. Deblois G, Smith HW, Tam IS, Gravel S-P, Caron M, Savage P, et al. ERR $\alpha$ mediates metabolic adaptations driving lapatinib resistance in breast cancer. Nat Commun. (2016) 7:12156. doi: 10.1038/ncomms12156

119. Park S, Chang C, Safi R, Liu X, Baldi R, Jasper JS, et al. ERR $\alpha$-regulated lactate metabolism contributes to resistance to targeted therapies in breast cancer. Cell Rep. (2016) 15:323-35. doi: 10.1016/j.celrep.2016.03.026
120. Baenke F, Chaneton B, Smith M, Van Den Broek N, Hogan K, Tang H, et al. Resistance to BRAF inhibitors induces glutamine dependency in melanoma cells. Mol Oncol. (2016) 10:73-84. doi: 10.1016/j.molonc.2015.08.003

121. Cesi G, Walbrecq G, Zimmer A, Kreis S, Haan C. ROS production induced by BRAF inhibitor treatment rewires metabolic processes affecting cell growth of melanoma cells. Mol Cancer (2017) 16:102. doi: 10.1186/s12943-017-0667-y

122. Corazao-Rozas P, Guerreschi P, Jendoubi M, Andr,é F, Jonneaux A, Scalbert $\mathrm{C}$, et al. Mitochondrial oxidative stress is the Achille's heel of melanoma cells resistant to Braf-mutant inhibitor. Oncotarget (2013) 4:1986-98. doi: 10.18632/oncotarget.1420

123. Zhang G, Frederick DT, Wu L, Wei Z, Krepler C, Srinivasan S, et al. Targeting mitochondrial biogenesis to overcome drug resistance to MAPK inhibitors. $J$ Clin Invest. (2016) 126:1834-56. doi: 10.1172/JCI82661

124. Li Y-Y, Wu C, Chen S-M, Shah SS, Wangpaichitr M, Feun LG, et al. BRAF inhibitor resistance enhances vulnerability to arginine deprivation in melanoma. Oncotarget (2016) 7:17665-80. doi: 10.18632/oncotarget.6882

125. Kaplon J, Zheng L, Meissl K, Chaneton B, Selivanov V, a, Mackay G, et al. A key role for mitochondrial gatekeeper pyruvate dehydrogenase in oncogeneinduced senescence. Nature (2013) 498:109-12. doi: 10.1038/nature12154

126. Ohanna M, Cerezo M, Nottet N, Bille K, Didier R, Beranger G, et al. Pivotal role of NAMPT in the switch of melanoma cells toward an invasive and drug-resistant phenotype. Genes Dev. (2018) 32:448-61. doi: 10.1101/gad.305854.117

127. Jin X, Pan Y, Wang L, Ma T, Zhang L, Tang AH, et al. Fructose-1,6bisphosphatase Inhibits ERK activation and bypasses gemcitabine resistance in pancreatic cancer by blocking IQGAP1-MAPK interaction. Cancer Res. (2017) 77:4328-41. doi: 10.1158/0008-5472.CAN-16-3143

128. Shukla SK, Purohit V, Mehla K, Gunda V, Chaika NV, Vernucci E, et al. MUC1 and HIF-1alpha signaling crosstalk induces anabolic glucose metabolism to impart gemcitabine resistance to pancreatic cancer. Cancer Cell (2017) 32:71-87.e7. doi: 10.1016/j.ccell.2017.06.004

129. Yang Y, Liu H, Li Z, Zhao Z, Yip-Schneider M, Fan Q, et al. Role of fatty acid synthase in gemcitabine and radiation resistance of pancreatic cancers. Int $J$ Biochem Mol Biol. (2011) 2:89-98.

130. Tadros S, Shukla SK, King RJ, Gunda V, Vernucci E, Abrego J, et al. De novo lipid synthesis facilitates gemcitabine resistance through endoplasmic reticulum stress in pancreatic cancer. Cancer Res. (2017) 77:5503-17. doi: 10.1158/0008-5472.CAN-16-3062

131. Chen R, Lai LA, Sullivan Y, Wong M, Wang L, Riddell J, et al. Disrupting glutamine metabolic pathways to sensitize gemcitabine-resistant pancreatic cancer. Sci Rep. (2017) 7:7950. doi: 10.1038/s41598-017-08436-6

132. Lo M, Ling V, Wang YZ, Gout PW. The xc- cystine/glutamate antiporter: a mediator of pancreatic cancer growth with a role in drug resistance. $\mathrm{Br} \mathrm{J}$ Cancer (2008) 99:464-72. doi: 10.1038/sj.bjc.6604485

133. Stäubert C, Bhuiyan H, Lindahl A, Broom OJ, Zhu Y, Islam S, et al. Rewired metabolism in drug-resistant leukemia cells: a metabolic switch hallmarked by reduced dependence on exogenous glutamine. J Biol Chem. (2015) 290:8348-59. doi: 10.1074/jbc.M114.618769

134. Zhu Y, Lu L, Qiao C, Shan Y, Li H, Qian S, et al. Targeting PFKFB3 sensitizes chronic myelogenous leukemia cells to tyrosine kinase inhibitor. Oncogene (2018) 37:2837-49. doi: 10.1038/s41388-018-0157-8

135. Kuntz EM, Baquero P, Michie AM, Dunn K, Tardito S, Holyoake TL, et al. Targeting mitochondrial oxidative phosphorylation eradicates therapyresistant chronic myeloid leukemia stem cells. Nat Med. (2017) 23:1234-40. doi: $10.1038 / \mathrm{nm} .4399$

136. Farge T, Saland E, de Toni F, Aroua N, Hosseini M, Perry R, et al. Chemotherapy-resistant human acute myeloid leukemia cells are not enriched for leukemic stem cells but require oxidative metabolism. Cancer Discov. (2017) 7:716-35. doi: 10.1158/2159-8290.CD-16-0441

137. Kim M-J, Choi Y-K, Park SY, Jang SY, Lee JY, Ham HJ, et al. PPAR $\delta$ reprograms glutamine metabolism in sorafenib-resistant HCC. Mol Cancer Res. (2017) 15:1230-42. doi: 10.1158/1541-7786.MCR-17-0061

138. Fukuda S, Miyata H, Miyazaki Y, Makino T, Takahashi T, Kurokawa $\mathrm{Y}$, et al. Pyruvate kinase M2 modulates esophageal squamous cell carcinoma chemotherapy response by regulating the pentose phosphate pathway. Ann Surg Oncol. (2015) 22:1461-8. doi: 10.1245/s10434-0154522-3 
139. Mims J, Bansal N, Bharadwaj MS, Chen X, Molina AJ, Tsang AW, et al. Energy metabolism in a matched model of radiation resistance for head and neck squamous cell cancer. Radiat Res. (2015) 183:291-304. doi: $10.1667 /$ RR13828.1

140. Mynhardt C, Damelin LH, Jivan R, Peres J, Prince S, Veale RB, et al. Metformin-induced alterations in nucleotide metabolism cause 5fluorouracil resistance but gemcitabine susceptibility in oesophageal squamous cell carcinoma. J Cell Biochem. (2017) 119:1193-203. doi: $10.1002 /$ jcb. 26291

141. Zhou Y, Tozzi F, Chen J, Fan F, Xia L, Wang J, et al. Intracellular ATP levels are a pivotal determinant of chemoresistance in colon cancer cells. Cancer Res. (2012) 72:304-14. doi: 10.1158/0008-5472.CAN-11-1674

142. Ma L, Cheng Q. Inhibiting 6-phosphogluconate dehydrogenase reverses doxorubicin resistance in anaplastic thyroid cancer via inhibiting NADPHdependent metabolic reprogramming. Biochem Biophys Res Commun. (2018) 498:912-7. doi: 10.1016/j.bbrc.2018.03.079

143. Moreau P, Richardson PG, Cavo M, Orlowski RZ, San Miguel JF, Palumbo A, et al. Proteasome inhibitors in multiple myeloma: 10 years later. Blood (2012) 120:947-59. doi: 10.1182/blood-2012-04-403733

144. Anderson KC. The 39th David A. Karnofsky Lecture: bench-to-bedside translation of targeted therapies in multiple myeloma. J Clin Oncol. (2012) 30:445-52. doi: 10.1200/JCO.2011.37.8919

145. Obeng EA, Carlson LM, Gutman DM, Harrington WJ, Lee KP, Boise LH. Proteasome inhibitors induce a terminal unfolded protein response in multiple myeloma cells. Blood (2006) 107:4907-16. doi: 10.1182/blood-2005-08-3531

146. Lipchick BC, Fink EE, Nikiforov MA. Oxidative stress and proteasome inhibitors in multiple myeloma. Pharmacol Res. (2016) 105:210-5. doi: 10.1016/j.phrs.2016.01.029

147. Niewerth D, Jansen G, Assaraf YG, Zweegman S, Kaspers GJL, Cloos J. Molecular basis of resistance to proteasome inhibitors in hematological malignancies. Drug Resist Updat. (2015) 18:18-35. doi: 10.1016/j.drup.2014.12.001

148. Orlowski RZ, Kuhn DJ. Proteasome inhibitors in cancer therapy: lessons from the first decade. Clin Cancer Res. (2008) 14:1649-57. doi: 10.1158/1078-0432.CCR-07-2218

149. Oerlemans R, Franke NE, Assaraf YG, Cloos J, van Zantwijk I, Berkers CR, et al. Molecular basis of bortezomib resistance: proteasome subunit beta5 (PSMB5) gene mutation and overexpression of PSMB5 protein. Blood (2008) 112:2489-99. doi: 10.1182/blood-2007-08-104950

150. Franke NE, Niewerth D, Assaraf YG, van Meerloo J, Vojtekova K, van Zantwijk $\mathrm{CH}$, et al. Impaired bortezomib binding to mutant $\beta 5$ subunit of the proteasome is the underlying basis for bortezomib resistance in leukemia cells. Leukemia (2012) 26:757-68. doi: 10.1038/leu.2011.256

151. de Wilt LHAM, Jansen G, Assaraf YG, van Meerloo J, Cloos J, Schimmer AD, et al. Proteasome-based mechanisms of intrinsic and acquired bortezomib resistance in non-small cell lung cancer. Biochem Pharmacol. (2012) 83:20717. doi: 10.1016/j.bcp.2011.10.009

152. Rückrich T, Kraus M, Gogel J, Beck A, Ovaa H, Verdoes M, et al. Characterization of the ubiquitin-proteasome system in bortezomib-adapted cells. Leukemia (2009) 23:1098-105. doi: 10.1038/leu.2009.8

153. Balsas P, Galán-Malo P, Marzo I, Naval J. Bortezomib resistance in a myeloma cell line is associated to PSM 35 overexpression and polyploidy. Leuk Res. (2012) 36:212-8. doi: 10.1016/j.leukres.2011.09.011

154. Niewerth D, Kaspers GJL, Jansen G, van Meerloo J, Zweegman S, Jenkins G, et al. Proteasome subunit expression analysis and chemosensitivity in relapsed paediatric acute leukaemia patients receiving bortezomib-containing chemotherapy. J Hematol Oncol. (2016) 9:82. doi: 10.1186/s13045-016-0312-z

155. Dettmer S, Theile D, Schäfer J, Seckinger A, Burhenne J, Weiss J. Proteasome inhibition correlates with intracellular bortezomib concentrations but not with antiproliferative effects after bolus treatment in myeloma cell lines. Naunyn Schmiedebergs Arch Pharmacol. (2016) 389:1091-101. doi: 10.1007/s00210-016-1276-9

156. Ling SCW, Lau EKK, Al-Shabeeb A, Nikolic A, Catalano A, Iland H, et al. Response of myeloma to the proteasome inhibitor bortezomib is correlated with the unfolded protein response regulator XBP-1. Haematologica (2012) 97:64-72. doi: 10.3324/haematol.2011.043331
157. Leung-Hagesteijn C, Erdmann N, Cheung G, Keats JJ, Stewart AK, Reece DE, et al. Xbp1s-negative tumor B cells and pre-plasmablasts mediate therapeutic proteasome inhibitor resistance in multiple myeloma. Cancer Cell (2013) 24:289-304. doi: 10.1016/j.ccr.2013.08.009

158. Driessen C, Kraus M, Joerger M, Rosing H, Bader J, Hitz F, et al. Treatment with the HIV protease inhibitor nelfinavir triggers the unfolded protein response and may overcome proteasome inhibitor resistance of multiple myeloma in combination with bortezomib: a phase I trial (SAKK 65/08). Haematologica (2016) 101:346-55. doi: 10.3324/haematol.2015.135780

159. Franke NE, Kaspers GL, Assaraf YG, van Meerloo J, Niewerth D, Kessler FL, et al. Exocytosis of polyubiquitinated proteins in bortezomib-resistant leukemia cells: a role for MARCKS in acquired resistance to proteasome inhibitors. Oncotarget (2016) 7:74779-96. doi: 10.18632/oncotarget.11340

160. Galluzzi L, Kepp O, Vander Heiden MG, Kroemer G. Metabolic targets for cancer therapy. Nat Rev Drug Discov. (2013) 12:829-46. doi: $10.1038 / \mathrm{nrd} 4145$

161. Chen HHW, Kuo MT. Role of glutathione in the regulation of cisplatin resistance in cancer chemotherapy. Met Based Drugs (2010) 2010:1-7. doi: $10.1155 / 2010 / 430939$

162. Leyton J, Latigo JR, Perumal M, Dhaliwal H, He Q, Aboagye EO. Early detection of tumor response to chemotherapy by 3'-deoxy-3'[18F]fluorothymidine positron emission tomography: the effect of cisplatin on a fibrosarcoma tumor model in vivo. Cancer Res. (2005) 65:4202-10. doi: 10.1158/0008-5472.CAN-04-4008

163. Shi H, Zhang W, Zhi Q, Jiang M. Lapatinib resistance in HER2+ cancers: latest findings and new concepts on molecular mechanisms. Tumor Biol. (2016) 37:15411-31. doi: 10.1007/s13277-016-5467-2

164. D’Amato V, Raimondo L, Formisano L, Giuliano M, De Placido S, Rosa $\mathrm{R}$, et al. Mechanisms of lapatinib resistance in HER2-driven breast cancer. Cancer Treat Rev. (2015) 41:877-83. doi: 10.1016/j.ctrv.2015.08.001

165. Janzer A, German NJ, Gonzalez-Herrera KN, Asara JM, Haigis MC, Struhl K. Metformin and phenformin deplete tricarboxylic acid cycle and glycolytic intermediates during cell transformation and NTPs in cancer stem cells. Proc Natl Acad Sci USA. (2014) 111:10574-9. doi: 10.1073/pnas.1409844111

166. Yun J, Mullarky E, Lu C, Bosch KN, Kavalier A, Rivera K, et al. Vitamin C selectively kills KRAS and BRAF mutant colorectal cancer cells by targeting GAPDH. Science (2015) 350:1391-6. doi: 10.1126/science.aaa5004

167. Aird KM, Allensworth JL, Batinic-Haberle I, Lyerly HK, Dewhirst MW, Devi GR. ErbB1/2 tyrosine kinase inhibitor mediates oxidative stress-induced apoptosis in inflammatory breast cancer cells. Breast Cancer Res Treat. (2012) 132:109-19. doi: 10.1007/s10549-011-1568-1

168. Teppo H-R, Soini Y, Karihtala P. Reactive oxygen species-mediated mechanisms of action of targeted cancer therapy. Oxid Med Cell Longev. (2017) 2017:1-11. doi: 10.1155/2017/1485283

169. Conklin KA. Chemotherapy-associated oxidative stress: impact on chemotherapeutic effectiveness. Integr Cancer Ther. (2004) 3:294-300. doi: 10.1177/1534735404270335

170. Sullivan LB, Gui DY, Vander Heiden MG. Altered metabolite levels in cancer: implications for tumour biology and cancer therapy. Nat Rev Cancer (2016) 16:680-93. doi: 10.1038/nrc.2016.85

171. Wojtkowiak JW, Verduzco D, Schramm KJ, Gillies RJ. Drug resistance and cellular adaptation to tumor acidic $\mathrm{pH}$ microenvironment. Mol Pharm. (2011) 8:2032-8. doi: 10.1021/mp200292c

172. Vukovic V, Tannock IF. Influence of low $\mathrm{pH}$ on cytotoxicity of paclitaxel, mitoxantrone and topotecan. Br J Cancer (1997) 75:1167-72. doi: 10.1038/bjc.1997.201

173. Wise DR, Thompson CB. Glutamine addiction: a new therapeutic target in cancer. Trends Biochem Sci. (2010) 35:427-33. doi: 10.1016/j.tibs.2010. 05.003

174. Smith B, Schafer XL, Ambeskovic A, Spencer CM, Land H, Munger J. Addiction to coupling of the warburg effect with glutamine catabolism in cancer cells. Cell Rep. (2016) 17:821-36. doi: 10.1016/j.celrep.2016. 09.045

175. Bridges HR, Jones AJY, Pollak MN, Hirst J. Effects of metformin and other biguanides on oxidative phosphorylation in mitochondria. Biochem J. (2014) 462:475-87. doi: 10.1042/BJ20140620

176. Mayers JR, Torrence ME, Danai LV, Papagiannakopoulos T, Davidson SM, Bauer MR, et al. Tissue of origin dictates branched-chain amino acid 
metabolism in mutant Kras-driven cancers. Science (2016) 353:1161-5. doi: 10.1126/science.aaf5171

177. Maddocks ODK, Berkers CR, Mason SM, Zheng L, Blyth K, Gottlieb E, et al. Serine starvation induces stress and p53-dependent metabolic remodelling in cancer cells. Nature (2013) 493:542-6. doi: 10.1038/nature11743

178. Krishnan N, Dickman MB, Becker DF. Proline modulates the intracellular redox environment and protects mammalian cells against oxidative stress. Free Radic Biol Med. (2008) 44:671-81. doi: 10.1016/j.freeradbiomed.2007.10.054

179. Kremer JC, Prudner BC, Lange SES, Bean GR, Schultze MB, Brashears $\mathrm{CB}$, et al. Arginine deprivation inhibits the warburg effect and upregulates glutamine anaplerosis and serine biosynthesis in ASS1-deficient cancers. Cell Rep. (2017) 18:991-1004. doi: 10.1016/j.celrep.2016.12.077

180. Farwell MD, Pryma DA, Mankoff DA. PET/CT imaging in cancer: current applications and future directions. Cancer (2014) 120:3433-45. doi: $10.1002 /$ cncr. 28860

181. Farber S, Diamond LK. Temporary remissions in acute leukemia in children produced by folic acid antagonist, 4-aminopteroyl-glutamic acid. N Engl J Med. (1948) 238:787-93. doi: 10.1056/NEJM194806032 382301

182. Masetti R, Pession A. First-line treatment of acute lymphoblastic leukemia with pegasparaginase. Biologics (2009) 3:359-68.

183. Martinez-Outschoorn UE, Peiris-Pagés M, Pestell RG, Sotgia F, Lisanti MP. Cancer metabolism: a therapeutic perspective. Nat Rev Clin Oncol. (2017) 14:11-31. doi: 10.1038/nrclinonc.2016.60

Conflict of Interest Statement: The authors declare that the research was conducted in the absence of any commercial or financial relationships that could be construed as a potential conflict of interest.

Copyright $\odot 2018$ Zaal and Berkers. This is an open-access article distributed under the terms of the Creative Commons Attribution License (CC BY). The use, distribution or reproduction in other forums is permitted, provided the original author(s) and the copyright owner(s) are credited and that the original publication in this journal is cited, in accordance with accepted academic practice. No use, distribution or reproduction is permitted which does not comply with these terms. 